Bu makaleye atıfta bulunmak için/To cite this article:

TURAN, S. KORAY, Ö. KAHRAMAN, E. (2021). Ortaöğretim Öğrencilerinin Geribildirim Deneyimlerinin

Cinsiyet, Sınıf ve Okul Düzeyi Değişkenleri Açısından İncelenmesi. Atatürk Üniversitesi Sosyal Bilimler

Enstitüsü Dergisi, 25 (Özel Sayı), 290-312.

\title{
Ortaöğretim Öğrencilerinin Geribildirim Deneyimlerinin Cinsiyet, Sınıf ve Okul Düzeyi Değişkenleri Açısından İncelenmesi ${ }^{*}$
}

\author{
Seçil TURAN ${ }^{(* *)}$ \\ Özlem KORAY $Y^{(* * *)}$ \\ Emine KAHRAMAN ${ }^{(* * *)}$
}

$\ddot{O}_{z:}$ Bu araștırmada öğrencilerin var olan geribildirim deneyimleri ve bu deneyimlerin cinsiyet, okul ve sinıf düzeyi değişkenleri açısından nasıl farklılaştı̆̆ının incelenmesi amaçlanmıştır. Çalışmada tarama modeli kullanılmıştır. Araştırma 2018-2019 eğitim öğretim yılı ikinci döneminde Zonguldak'ın iki ilçesinde bulunan Fen, Anadolu ve Endüstri Meslek Liselerinde ögrenim gören farklı sinıf seviyelerindeki öğrencilerle gerçekleştirilmiştir. Araştırmanın örneklemi sekiz ortaöğretim kurumunda ögrrenim gören 1041 ögrenciden oluşmaktadir. Ortä̈gretim ögrrencilerinin geribildirim deneyimlerini ortaya çıkarmak için "Geribildirim Deneyimi Ölçeği (GDÖ)” veri toplama aracı olarak kullanılmıştır. Ölçeğin faktör analizi çalışmaları yapılmış olup, bu çalı̧̧ma için yeterli geçerlik ve güvenirlikte olduğu belirlenmiştir. Verilerin analizinde, betimsel ve karşılaştırmalı istatistikler kullanılmıştır. Araştırmanın sonuçlarına göre kiz ögrencilerin erkek ögrrencilere göre geribildirimi daha fazla öğrenme sürecinde algıladiklarl ve kullandlklarl bulunmuştur. Buna ek olarak araştırma, tüm sınıf düzeyindeki ögrencilerin ögrrenme sürecinde alınan geribildirimin öneminin farkında olduklarını göstermiştir.

\section{Anahtar Kelimeler: Geribildirim, geribildirim deneyimi, ortaöğretim öğrencileri \\ Investigation of Secondary School Students' Feedback Experiences in Terms of Gender, Class and School Level Variables}

Abstract: The purpose of this study was to reveal the current feedback experiences of the students and to examine whereby these experiences differ in terms of gender, school, and grade levels. In the research, the survey model was used as a research method. The sample of the study consists of 1041 students studying. "Feedback Experience Scale" was used as a data collection tool. It has been decided that this scale has sufficient validity and reliability. The feedback

*) Bu çalışma birinci yazarın yüksek lisans tezinden üretilmiştir.

${ }^{* *}$ Öğretmen, Karadeniz Ereğli Mehmet Ali ve Kadri Yılmaz Anadolu Lisesi (e-posta: sclturan@hotmail.com) (D) ORCID ID.https://orcid.org/0000-0002-0146-5788

${ }^{* * *}$ Prof. Dr., Zonguldak Bülent Ecevit Üniversitesi Ereğli Eğitim Fakültesi Matematik ve Fen Bilimleri Eğitimi Bölümü (e-posta: ocankoray@gmail.com) (D ORCID ID.https://orcid.org/00000003-1804-0871

${ }^{* * * *)}$ Arş. Gör. Dr., Zonguldak Bülent Ecevit Üniversitesi Ereğli Eğitim Fakültesi Matematik ve Fen Bilimleri Eğitimi Bölümü (e-posta:eminekahraman07@gmail.com) (D) ORCID ID. https://orcid.org/0000-0002-0721-9545

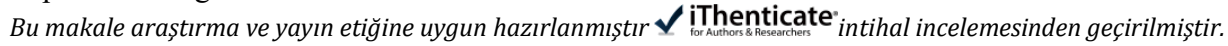


experiences of the students have analyzed based on gender, grade level, and school-level variables, and frequency and percentage value. In the analysis of the data, descriptive and comparative statistics were used. According to the results of the study, it was found that female students perceive and use feedback more during the learning process. Students at all grade and school-levels are aware of the importance of feedback received during the learning process.

Keywords: Feedback, feedback experience, secondary school students

Makale Geliş Tarihi: 15.05.2020

Makale Kabul Tarihi: 15.11.2021

DOI: 10.53487/ataunisosbil.737917

\section{Giriş}

Değerlendirme uygulamaları eğitim ve öğretim sürecinde öğrencilerin öğrenme eksikliklerinin belirlenmesinde ve giderilmesinde öğretmenlere yardımcı olmaktadır. Değerlendirme, bir ölçüte göre ölçme sonuçlarının karşılaştırma yapılmasına ve ölçülen niteliğe yönelik olarak bir yargıya varılmasına denir (Atılgan, 2017; Semerci, 2008). Eğitim sisteminde değerlendirme öğrencilere, öğretmenlere, yöneticilere ve programlara yönelik alınacak kararların hedeflere uygun ve doğru olarak yapılabilmesi için yol göstericidir (Bahar vd., 2012). Yani, öğrenme sürecinde ölçme işleminden sonra yapılacak çalışmalara rehberlik etmektedir (Cemiloğlu, 2001). Ayrıca öğretim sürecinde yapılan değerlendirme yaklaşımları, öğretim programlarında meydana gelen değişime bağlı olarak değişiklikler göstermektedir. Öğretim sürecinde öğrenciyi merkeze alan öğretim programlarında, belirlenen amaçlar doğrultusunda biçimlendirici değerlendirmenin kullanılması vurgulanmaktadır (Vollmeyer \& Rheinberg, 2005). Biçimlendirici değerlendirme sürecinde öğrencinin tercih ettiği öğrenme biçimlerinin yanında farklı teknikler ve yöntemler kullanılır (Doğan, 2016). Biçimlendirici değerlendirme süreci sadece sonuç odaklı değil, aynı zamanda süreci de odağına alarak öğrenciyi değerlendirmeyi hedefler (Kahraman ve Koray, 2020).

Biçimlendirici değerlendirmenin önemli kriterlerinden biri öğrencilere verilen geribildirimlerdir. Geribildirim, öğretim sürecinde öğrencinin performansına yönelik olarak verilen bilgidir (Butler \& Winne, 1995). Geribildirim öğrencilerin öğrenmelerine, becerilerine veya verilen herhangi bir göreve yönelik olarak öğrencinin sahip olduğu bilgi düzeyidir. Öğrencilere verilen geribildirimler öğrencilerin kendi düşüncelerinin, bilgi düzeylerinin ve öğrenme biçimlerinin farkında olmasına ve böylelikle kendilerine eleştirel bir bakış açısıyla yaklaşmalarına yardımcı olmaktadır (Korkmaz, 2004). Ayrıca geribildirimler öğrencilerin sahip olduğu performansa yönelik zayıf ve güçlü yönleri hakkında bilgi vererek, buna yönelik olarak ileride yapılacak çalışmaların verimliliğinin artmasına neden olmaktadır (Weaver, 2006). Bu nedenle eğitim ortamında verilen geribildirimler öğrencilerin öğrenme sürecindeki yanlışların düzeltilmesinin yanında, öğrencilerin derse yönelik motivasyonlarının artmasına katkı sağlayarak onların derse katılımını olumlu yönde etkilemektedir (Bose \& Rengel, 2009).

Öğretilen konunun içeriğine ve doğasına bağlı olarak kullanılan geribildirimler sözlü, yazılı veya gösteri şeklinde olabilmektedir (Brookhart \& Moss, 2009). Bu nedenle 
Ortaögrretim Öğrencilerinin Geribildirim Deneyimlerinin Cinsiyet, Sinıf ve Okul Düzeyi Değişkenleri Açısından İncelenmesi

öğretim sürecinde verilen geribildirimin etkinliği, öğretime olan uygunluğuna bağlıdır (İrons, 2008). Öğretim sürecinde verilen geribildirimler hem öğrenme ve öğretmede etkili olmalı, hem de öğrencilerin performanslarını geliştirici nitelikte olmalıdır. Özellikle sürece uygun olarak zamanında verilen kaliteli ve kapsayıcı geribildirimler öğrencilerin öğrenmelerinde olumlu etki yapmaktadır (Lee, 2017). Geribildirimler öğrencinin kendi öğrenmeleri üzerinde düşünmesini sağlayarak öğrenme süreçlerini izleyebilmelerine yardımcı olmaktadır. Ayrıca geribildirimler öğrencilerin öğrenme sürecinde yaptığ çalışmaların kalitesini arttırarak öz düzenleme becerilerini geliştirir (Brookhart \& Moss, 2009; Fautley \& Savage, 2008; Sadler, 2010).

Geribildirimlerin öğrencilerin öğrenmelerinde önemli bir etki gücüne sahip olduğunu gösteren araştırmalar yapılmıştır (Güven, 2004; Higgins, Hartley \& Skelton, 2002; Koray, 2016; Lipnevich \& Smith, 2008; Peterson \& Irving, 2008; Poulos \& Mahony, 2008). Geribildirimler sınıf ortamındaki iletişim sürecinde alıcı ve verici arasındaki ilişkileri içerdiği için öğrenmeyi etkilemektedir (Askew \& Lodge, 2000). Bu ilişkinin farklı zamanlarda ve yollarla verilmesi öğrencinin performansına olumlu katkılar sağlamaktadır (Butler \& Winne, 1995; Ilgen, Fisher \& Taylor, 1979). Panasuk ve Lebaron (1999) öğrencinin gösterdiği performansa yönelik olarak aktarılan bilgilerin öğrencilerin öğrenme düzeylerini arttırmada yol gösterici olduğunu vurgulamıştır. Bu açıdan geribildirimler, öğrencilerin öğrenmelerinin düzenlenmesine ve öz değerlendirme yapmalarına imkân sağlamaktadır (Nicol \& Macfarlane-Dick, 2006).

Öğrenme sürecinde kullanılan geribildirimler, öğrenme hedeflerine ulaşıllp ulaşılmadığını gösterir nitelikte olmalıdır. Ayrıca öğrencilerin çalışmalarının kalitesini arttırıcı özellikte olmalıdır (Hounsell, 2007). Lee (2008) zamanında ve iyi yapılandırılmış geribildirimin etkisinin, beklenenden daha fazla olabileceğini vurgulamıştır. Yani bu süreç öğrenciyi hem bilişsel, hem de duyuşsal olarak etkileyebilir. Lee (2008) iyi yapılandırılmış geribildirimlerin öğrencilerin ihtiyacına göre şekillendiğini ve hangi konuya yönelik bilgiye ihtiyaç varsa onunla ilgili bilgi içermesi gerektiğini vurgulamıştır. Geribildirimlerin öğrencilerin mevcut öğrenmeleri hakkında yeterince bilgilendirici olması ve sonraki aşamada ne yapmaları gerektiği konusunda yönlendirici olması gerekmektedir.

Öğrencilerin geribildirime verecekleri karşılık, geribildirime yönelik algıları ve deneyimleri ile ilişkilidir (Weaver, 2006). Geribildirimlerin öğrencini öğrenme performansını etkilemesi için, onun bu sürece yönelik olumlu bir algısının olması gerektirmektedir. Bazı çalışmalar öğrencilerin verilen geribildirimleri zaman zaman kullanmadıklarını ifade etmektedir (Glower \& Brown, 2006). Bunun nedeni, öğrencilerin geribildirimlerin öğrenmede etkili olmadığı yönündeki inanç ve algıları olabilir (Jonsson, 2012). Bu nedenle verilen geribildirimin etkililiğini değerlendirirken öncelikle öğrencilerin geribildirim deneyimlerinin dikkate alınması gerekmektedir (Poulos \& Mohony, 2008). Öğrenme sürecinde kullanılan geribildirimler öğrenci tarafından doğru algılanmıyorsa veya öğrenmeye katkı sağlamıyorsa bu süreçte kullanılması anlamsızdır. Bu durumda eğitim öğretim sürecinde öğrencilerin mevcut geribildirim deneyimlerinin ortaya koyulması, yanlış ve eksik algılanmalarının belirlenmesi, gerekli düzeltmelerin yapılması öğrenmenin verimliliği açısından önemlidir. 
Öğretimsel süreçlerde kalitenin arttırılması adına yapılan pek çok çalışmada öğrenci geribildirim deneyimlerine çok az değinildiği hesaba katıldığında, bu çalışmanın alan literatürüne katkı sağlayacă̆ söylenebilir. Ayrıca ulaşılan sonuçların ülkemizin eğitimöğretimin kalitesinin geliştirilmesi ve artırılması için öğrencilere, program hazırlayıcılara ve öğretmenlere yol göstereceği düşünülmektedir. Bununla birlikte öğrencilere öğretim sürecinde verilen geribildirimlerin kalitesinin, miktarının ve zamanın belirlenmesi, onlara verilen geribildirimlerin tekrar gözden geçirilip eksikliklerinin giderilmesi noktasında büyük önem taşımaktadır. $\mathrm{Bu}$ araştırmada öğrencilerin mevcut geribildirim deneyimlerinin ortaya koyulması ve bu deneyimlerin cinsiyet, okul ve sınıf düzeyi değişkenleri açısından nasıl farklılaştı̆ı̆ının incelenmesi amaçlanmıştır. Bu amaç doğrultusunda araştırmanın alt problemleri şunlardır:

1. Ortaöğretim öğrencilerinin cinsiyet değişkeni açısından geribildirim deneyimleri nasıldır?

2. Ortaöğretim öğrencilerinin sınıf düzeyi değişkeni açısından geribildirim deneyimleri nasıldır?

3. Ortaöğretim öğrencilerinin okul düzeyi değişkeni açısından geribildirim deneyimleri nasıldır?

4. Ortaöğretim öğrencilerinin geribildirim deneyimi cinsiyet türü değişkenine göre nasıl farklılaşmaktadır?

5. Ortaöğretim öğrencilerinin geribildirim deneyimi sınıf düzeyi değişkenine göre nasıl farklılaşmaktadır?

6. Ortaöğretim öğrencilerinin geribildirim deneyimi okul düzeyi değişkenine göre nasıl farklılaşmaktadır?

\section{Yöntem}

\section{A. Araştırmanın Modeli}

$\mathrm{Bu}$ araştırmada tarama modeli kullanılmıştır. Tarama modeli çalışmaya konu olan bireylerin mevcut özelliklerinin objektif olarak araştırılmasına imkân verir (Büyüköztürk, Kılıç Çakmak, Akgün, Karadeniz ve Demirel, 2021). Bu araştırma modelinde hedeflenen grubun tamamına ulaşılamasa da hedeflenen grubun özelliklerini taşıyacak ve temsil edecek örneklem seçilir (Karasar, 2020). Bu çalışmada mevcut olan durumun değiştirilmesi veya birbirinden etkilenme kaygısı olmadan, problemle ilgili veriler toplanarak değerlendirme yapılmıştır.

\section{B. Araştırmanın Evreni ve Örneklemi}

Araştırma, 2018-2019 eğitim-öğretim y1lı ikinci döneminde Zonguldak'ın iki ilçesinde bulunan Fen, Anadolu ve Endüstri Meslek Liselerinde öğrenim görmekte olan farklı sınıf düzeylerindeki öğrencilerle yapılmıştır. Çalışmanın evrenine ve örneklemine ait bilgiler Tablo 1'de verilmiştir. 
Ortaöğretim Öğrencilerinin Geribildirim Deneyimlerinin Cinsiyet, Sinıf ve Okul Düzeyi Değişkenleri Açısından İncelenmesi

Tablo 1: Araştırmanın evrenini ve örneklemini oluşturan öğrenci ve okul sayısı

\begin{tabular}{|c|c|c|c|c|c|}
\hline \multirow{3}{*}{$\begin{array}{l}\text { Evrendeki } \\
\text { Okul Sayısı }\end{array}$} & \multirow{2}{*}{$\begin{array}{l}\text { Evrendeki } \\
\text { Öğrenci Sayıs }\end{array}$} & \multicolumn{2}{|c|}{ Tabakadaki (Örneklem) } & \multicolumn{2}{|c|}{ Tabakadaki (Örneklem } \\
\hline & & $\overline{\mathrm{Okul}}$ & Tabaka Ağırlığ & Öğrenci & Tabaka \\
\hline & & Say1s1 & $\%$ & Say1s1 & Ağgrlığg $1 \%$ \\
\hline$\overline{23}$ & 11.940 & 8 & 34.7 & 1041 & 8.7 \\
\hline
\end{tabular}

Tablo 1'de verilen bilgilere göre araştırmanın evrenini 23 okulda öğrenim gören 11.940 öğrenci oluşturmaktadır. Araştırmanın örneklemini ise bu okulların 8 (\% 34.7) tanesinde öğrenim gören 1041 öğrenci (\% 8.7) oluşturmaktadır.

Çalışmanın örneklem grubu içinde toplam 8 lise gruplandırılarak (B1, B2, B3, B4, B5, B6, B7, B8) tabakalı örneklem yöntemi ile seçilmiştir. Okul düzeylerinin bu şekilde gruplandırılmasında öğrencilerin 2017-2018 eğitim-öğretim yılındaki TEOG başarı puanları dikkate alınmıştır. Öğrencilerin TEOG başarı puanlarına göre çalışmaya seçilen liseler; başarı puanı en yüksek olan liseler "birinci düzey", başarı puanı orta düzeyde olan liseler "ikinci düzey" ve başarı puanı en düşük olan liseler "üçüncü düzey" olarak gruplandırılmıştır. Araştırmanın örnekleminde yer alan öğrencilerin cinsiyet, sınıf düzeyi ve okul düzeyine göre frekans ve yüzde değerleri Tablo 2'de verilmiştir.

Tablo 2: Araştırmanın örneklemini oluşturan öğrencilerin cinsiyet, sınıf ve okul düzeyine göre frekans ve yüzdesi

\begin{tabular}{lccllllll}
\hline Cinsiyet & $\mathbf{f}$ & $\mathbf{\%}$ & Sinıf Düzeyi & $\mathbf{f}$ & $\mathbf{\%}$ & Okul Düzeyi & f & \% \\
\hline Kız & 470 & 45.1 & Dokuzuncu Sınıf & 269 & 25.8 & Birinci Düzey & 452 & 43.4 \\
Erkek & 571 & 54.9 & Onuncu Sınıf & 280 & 26.9 & İkinci Düzey & 363 & 34.3 \\
& & & On birinci Sinıf & 250 & 24.1 & Üçüncü Düzey & 226 & 21.3 \\
& & & On ikinci Sınıf & 242 & 23.2 & & & \\
Toplam & 1041100 & Toplam & 1041 & 100 & Toplam & 1041 & 100 \\
\hline
\end{tabular}

Tablo 2'ye göre araştırmaya birinci düzey okuldan toplam 452 (\% 43.4), ikinci düzey okuldan 363 (\% 34.3) ve üçüncü düzey okuldan 226 (\% 21.3) öğrenci katılmıştır. Araştırmaya katılan 1041 öğrenciden 470'i (\% 45.1) kız, 571'i (\% 54.9) erkektir. Bu öğrencilerden 269'u (\% 25.8) dokuzuncu sınıf, 280’i (\% 26.9) onuncu sınıf, 250’si (\% 24) on birinci sinıf ve 242'si (\% 23.2) on ikinci sinıf seviyesindedir.

\section{Veri Toplama Aracı ve Süreci}

Araştırmada veri toplama aracı olarak ortaöğretim öğrencilerine yönelik "Geribildirim Deneyimi Ölçeği (GDÖ)" kullanılmıştır. Gibbs ve Simpson (2003) tarafından geliştirilen Değerlendirme Deneyimi Ölçeği (Assessment Experience Questionnaire) temel alınarak ve yeni maddeler eklenerek oluşturulan ölçek, toplamda 17 maddeden oluşmaktadır. Ölçeği uyarlama sürecinde araştırmacılar gerekli izinleri almıştır. Ölçeğin uyarlama sürecinde pilot (222 öğrenciyle) ve gerçek (1041 öğrenciyle) uygulama yapılmıştır. Ölçek 5'li Likert tipinde olup "hiç katılmıyorum (1)", "katılmıyorum (2)", "kararsızım (3)", "katılıyorum (4)" ve "kesinlikle katılıyorum (5)" şeklinde derecelendirilmiştir. 
Uyarlanan ölçeğin güvenirlik ve geçerlik analizleri kapsamında madde analizi, faktör analizi ve güvenirlik katsayısı incelenmiştir. Ölçeğinin yapı geçerliği hem Açıklayıcı Faktör Analiziyle (AFA) hem de Doğrulayıcı Faktör Analizi (DFA) ile belirlenmiş̧tir. GDÖ’ne ait iç tutarll1ık Cronbach Alfa $(\alpha)$ güvenirliği 0.91 olarak belirlenmiştir. Ölçeğin alt boyutlarına ilişkin Cronbach Alfa katsayıları; geribildirim $=.89$ ve geribildirim miktarı ve zamanlamas $1=.63$ olarak bulunmuştur. Ölçeğin geribildirim boyutunda 14 madde ve geribildirimin miktarı ve zamanlaması boyutunda 3 madde bulunmaktadır. GDÖ'ye ait maddeler Tablo 3'de verilmiştir.

Tablo 3: Geribildirim deneyimi ölçek maddeleri

No Önermeler

1 "Geribildirimi dikkatlice okur ve ne söylediğini anlamaya çalışırım."

2 "Geribildirimler sonradan verilen ödevlerde bana yardımcı olur."

3 "Geribildirim, derste kullanmış olduğum materyallere tekrar göz atmam için beni yönlendirir."

4 "Ödevimde düzeltme yaparken geribildirimleri kullanırım."

5 "Geribildirimler konu hakkında eksik bilgilerimin farkına varmamı sağlar."

6 "Geribildirimler öğrenme sürecinde yol göstericidir."

7 "Geribildirimler, temelde diğerlerine göre ne kadar iyi yaptığımı anlamamı sağlar."

8 "Geribildirimler bana bir şeyleri daha iyi anlamam konusunda yardım eder."

9 "Geribildirimler çalışmamın bir dahaki sefere nasıl daha iyi yapabileceğimi gösterir."

10 "Geribildirimi okuduğum zaman neden o puanı aldığımı anlarım."

11 "Geribildirimler öğrenmenin kalitesinin arttırılmasında etkilidir."

12 "Geribildirimler hatalarımın farkına varmamı sağlar."

13 "Bir çalışmada (ödevde) neyi geliştirmem konusunda geribildirimler bana yardımcı olur."

14 "Birçok derste, başarı düzeyim konusunda geribildirim alırım."

15 "Geribildirimlerin bana dönüșü oldukça hızlıdır."

16 "Her dönem birçok derste geribildirim alırım."

17 "Sınav sonrasına geribildirim almam öğrenmemi sağlar."

Araştırma kapsamında GDÖ, 2018-2019 eğitim öğretim yılının ikinci döneminde farklı düzeylerde seçilen 8 okulda bir aylık süre içinde uygulanmıştır. Araştırma dâhilinde uygulanması hedeflenen sınıflar seçkisiz olarak belirlenmiştir. Ölçeğin uygulanması öncesinde öğrencilere, araştırmanın kapsamı ve amacına yönelik bilgilendirme yapılmıştır. Ölçeğin uygulanma sürecinde öğrencilerin gönüllü katılımı dikkate alınmış olup, ölçek 30 dakikalık bir sürede uygulanmıştır. 
Ortaöğretim Öğrencilerinin Geribildirim Deneyimlerinin Cinsiyet, Sinıf ve Okul Düzeyi Değişkenleri Açısından İncelenmesi

\section{Verilerin Analizi}

Verilerin analizinde SPSS 20 paket programı kullanılmıştır. Veri toplama araçlarından elde edilen veriler cinsiyet, sınıf düzeyi ve okul düzeyi değişkenlerine göre frekans ve yüzde değerleri bulunarak tablolaş̧ııılmışıı. Ayrıca öğrencilerin geribildirim deneyimleri, cinsiyet, sınıf ve okul düzeyi değişkenleri açısından karşılaştırılmıştır. Yapılan analizlerde gruplar arasındaki farklılığın belirlenmesinde öncelikle verilerin normallik varsayımları test edilmiş ve verilerin normal dağılmadığı belirlenmiştir. Veriler normal dağı̆lım göstermediğinden dolayı analiz sürecinde parametrik olmayan testler kullanılmıştır. Bu bağlamda araştırmada cinsiyet değişkenin farklılığını incelemek için Mann Whitney U-testi, sınıf ve okul düzeyi değişkenlerinin farklılığını incelemek için Kruskall Wallis H-testi kullanılmıştır.

\section{E. Araştırmanın Etik İzinleri}

Yapılan bu çalışmada "Yükseköğretim Kurumları Bilimsel Araştırma ve Yayın Etiği Yönergesi” kapsamında uyulması belirtilen tüm kurallara uyulmuştur. Yönergenin ikinci bölümü olan "Bilimsel Araştırma ve Yayın Etiğine Aykırı Eylemler" başlığı altında belirtilen eylemlerden hiçbiri gerçekleştirilmemiştir. Etik kurul izin bilgileri aşağıdaki gibidir:

Etik değerlendirmeyi yapan kurul adı $=$ Bülent Ecevit Üniversitesi İnsan Araştırmaları Etik Kurulu

Etik değerlendirme kararının tarihi $=29.03 .2019$

Etik değerlendirme belgesi sayı numarası $=540$

\section{Bulgular}

Bu bölümde araştırmanın amacına yönelik olarak GDÖ'den elde edilen bulgulara yer verilmiştir.

\section{A. Ortaöğretim Öğrencilerinin Geribildirim Deneyimlerinin Cinsiyet Değişkeni Açısından Frekans ve Yüzde Bulguları}

Ortaöğretim öğrencilerinin cinsiyet değişkeni açısından geribildirim deneyimleri incelenmiş ve bulgular Tablo 4'de verilmiştir.

Tablo 4: Ortaöğretim öğrencilerinin geribildirim deneyimlerinin cinsiyet değişkeni açısından frekans ve yüzde sonuçları

\begin{tabular}{|c|c|c|c|c|c|c|c|c|c|c|c|c|}
\hline \multirow[b]{3}{*}{ Madde } & \multicolumn{4}{|c|}{ Hiç Katılmıyorum } & \multicolumn{4}{|c|}{ Katılmıyorum } & \multicolumn{4}{|c|}{ Kararsızım } \\
\hline & \multicolumn{2}{|c|}{ K1z } & \multicolumn{2}{|c|}{ Erkek } & \multicolumn{2}{|c|}{ Kız } & \multicolumn{2}{|c|}{ Erkek } & \multicolumn{2}{|c|}{$\mathrm{K} 1 \mathrm{Z}$} & \multicolumn{2}{|c|}{ Erkek } \\
\hline & $\mathrm{f}$ & $\%$ & $\mathrm{f}$ & $\%$ & $\mathrm{f}$ & $\%$ & $\mathrm{f}$ & $\%$ & $\mathrm{f}$ & $\%$ & $\mathrm{f}$ & $\%$ \\
\hline 1 & 6 & 1.3 & 17 & 3.0 & 12 & 2.6 & 20 & 3.5 & 51 & 10.9 & 82 & 14.4 \\
\hline 2 & 10 & 2.1 & 20 & 3.5 & 21 & 4.5 & 64 & 11.2 & 92 & 19.6 & 118 & 20.7 \\
\hline 3 & 13 & 2.8 & 30 & 5.3 & 35 & 7.4 & 55 & 9.6 & 103 & 21.9 & 147 & 25.7 \\
\hline 4 & 11 & 2.3 & 29 & 5.1 & 19 & 4.0 & 57 & 10.0 & 101 & 21.5 & 122 & 21.4 \\
\hline 5 & 6 & 1.3 & 20 & 3.5 & 6 & 1.3 & 25 & 4.4 & 61 & 13.0 & 99 & 17.3 \\
\hline
\end{tabular}


Seçil TURAN

A T A S OBED

297 Özlem KORAY Emine KAHRAMAN

202125 (Özel Sayı): 290-312

\begin{tabular}{lllllllllllll}
\hline $\mathbf{6}$ & 9 & 1.9 & 21 & 3.7 & 6 & 1.3 & 25 & 4.4 & 69 & 14.7 & 104 & 18.2 \\
$\mathbf{7}$ & 10 & 2.1 & 25 & 4.4 & 25 & 5.3 & 42 & 7.4 & 132 & 28.1 & 169 & 29.6 \\
$\mathbf{8}$ & 11 & 2.3 & 18 & 3.2 & 13 & 2.8 & 35 & 6.1 & 69 & 14.7 & 104 & 18.2 \\
$\mathbf{9}$ & 8 & 1.7 & 20 & 3.5 & 14 & 3.0 & 51 & 8.9 & 78 & 16.6 & 99 & 17.3 \\
$\mathbf{1 0}$ & 7 & 1.5 & 34 & 6.0 & 16 & 3.4 & 50 & 8.8 & 78 & 16.6 & 107 & 18.7 \\
$\mathbf{1 1}$ & 10 & 2.1 & 25 & 4.4 & 22 & 4.7 & 47 & 8.2 & 99 & 21.1 & 116 & 20.3 \\
$\mathbf{1 2}$ & 6 & 1.3 & 16 & 2.8 & 8 & 1.7 & 30 & 5.3 & 56 & 11.9 & 99 & 17.3 \\
$\mathbf{1 3}$ & 13 & 2.8 & 33 & 5.8 & 15 & 3.2 & 45 & 7.9 & 86 & 18.3 & 115 & 20.1 \\
$\mathbf{1 4}$ & 30 & 6.4 & 56 & 9.8 & 85 & 18.1 & 107 & 18.7 & 162 & 34.5 & 164 & 28.7 \\
$\mathbf{1 5}$ & 45 & 9.6 & 90 & 15.8 & 84 & 17.9 & 110 & 19.3 & 204 & 43.4 & 181 & 31.7 \\
$\mathbf{1 6}$ & 38 & 8.1 & 73 & 12.8 & 80 & 17.0 & 118 & 20.7 & 172 & 36.6 & 170 & 29.8 \\
$\mathbf{1 7}$ & 11 & 2.3 & 31 & 5.4 & 17 & 3.6 & 34 & 6.0 & 69 & 14.7 & 90 & 15.8 \\
\hline
\end{tabular}

Tablo 4. devamı

\begin{tabular}{|c|c|c|c|c|c|c|c|c|c|c|c|c|}
\hline \multirow[b]{3}{*}{ Madde } & \multicolumn{4}{|c|}{ Katılıyorum } & \multicolumn{4}{|c|}{$\begin{array}{c}\text { Kesinlikle } \\
\text { Katılıyorum }\end{array}$} & \multicolumn{4}{|c|}{ Toplam } \\
\hline & \multicolumn{2}{|c|}{$\mathrm{K}_{1 \mathrm{Z}}$} & \multicolumn{2}{|c|}{ Erkek } & \multicolumn{2}{|c|}{ K1z } & \multicolumn{2}{|c|}{ Erkek } & \multicolumn{2}{|c|}{$\mathrm{K}_{1 \mathrm{z}}$} & \multicolumn{2}{|c|}{ Erkek } \\
\hline & $\mathrm{f}$ & $\%$ & $\mathrm{f}$ & $\%$ & $\mathrm{f}$ & $\%$ & $\mathrm{f}$ & $\%$ & $\mathrm{f}$ & $\%$ & $\mathrm{f}$ & $\%$ \\
\hline 1 & 254 & 54.0 & 284 & 49.7 & 147 & 31.3 & 168 & 29.4 & 470 & 100 & 571 & 100 \\
\hline 2 & 235 & 50.0 & 242 & 42.4 & 112 & 23.8 & 127 & 22.2 & 470 & 100 & 571 & 100 \\
\hline 3 & 244 & 51.9 & 241 & 42.2 & 75 & 16.0 & 98 & 17.2 & 470 & 100 & 571 & 100 \\
\hline 4 & 223 & 47.4 & 228 & 39.9 & 116 & 24.7 & 135 & 23.6 & 470 & 100 & 571 & 100 \\
\hline 5 & 201 & 42.8 & 235 & 41.2 & 196 & 41.7 & 192 & 33.6 & 470 & 100 & 571 & 100 \\
\hline 6 & 248 & 52.8 & 272 & 47.6 & 138 & 29.4 & 149 & 26.1 & 470 & 100 & 571 & 100 \\
\hline 7 & 206 & 43.8 & 230 & 40.3 & 97 & 20.6 & 105 & 18.4 & 470 & 100 & 571 & 100 \\
\hline 8 & 250 & 53.2 & 260 & 45.5 & 127 & 27.0 & 154 & 27.0 & 470 & 100 & 571 & 100 \\
\hline 9 & 237 & 50.4 & 236 & 41.3 & 133 & 28.3 & 165 & 28.9 & 470 & 100 & 571 & 100 \\
\hline 10 & 199 & 42.3 & 230 & 40.3 & 170 & 36.2 & 150 & 26.3 & 470 & 100 & 571 & 100 \\
\hline 11 & 222 & 47.2 & 236 & 41.3 & 117 & 24.9 & 147 & 25.7 & 470 & 100 & 571 & 100 \\
\hline 12 & 212 & 45.1 & 238 & 41.7 & 188 & 40.0 & 188 & 32.9 & 470 & 100 & 571 & 100 \\
\hline 13 & 237 & 50.4 & 250 & 43.8 & 119 & 25.3 & 128 & 22.4 & 470 & 100 & 571 & 100 \\
\hline 14 & 138 & 29.4 & 169 & 29.6 & 55 & 11.7 & 75 & 13.1 & 470 & 100 & 571 & 100 \\
\hline 15 & 106 & 22.6 & 127 & 22.2 & 31 & 6.6 & 63 & 11.0 & 470 & 100 & 571 & 100 \\
\hline 16 & 147 & 31.3 & 145 & 25.4 & 33 & 7.0 & 65 & 11.4 & 470 & 100 & 571 & 100 \\
\hline 17 & 233 & 49.7 & 247 & 43.3 & 139 & 29.6 & 169 & 29.6 & 469 & 100 & 571 & 100 \\
\hline
\end{tabular}

Tablo 4'e göre GDÖ’nün birinci maddesine en fazla kızların \% 85.3'ü, erkeklerin \%7 9.2'si "katılıyorum/kesinlikle katılıyorum" şeklinde cevaplamıştır. Ölçeğin ikinci maddesine en fazla kızların \% 73.8'i, erkeklerin \% 64.6's1 "katılıyorum/kesinlikle katılıyorum" şeklinde cevaplamıştır. Ölçeğin üçüncü maddesine en fazla kızların \% 67.9'u, erkeklerin \% 59.4'ü "katılıyorum/kesinlikle katılıyorum”" şeklinde cevaplamıştır. Ölçeğin dördüncü maddesine en fazla kızların \% 72.1'i, erkeklerin \% 63.6's1 "katılıyorum/kesinlikle katılıyorum” şeklinde cevaplamıştır. Ölçeğin beşinci maddesine 
Ortaöğretim Öğrencilerinin Geribildirim Deneyimlerinin Cinsiyet, Sinıf ve Okul Düzeyi Değişkenleri Açısından İncelenmesi

en fazla kızların \% 84.5'i, erkeklerin \% 74.8'i "katılıyorum/kesinlikle katılıyorum" şeklinde cevaplamıştır. Ölçeğin altıncı maddesine en fazla kızların \% 82.1'i, erkeklerin \% 73.7'si "katılıyorum/kesinlikle katılıyorum” şeklinde cevaplamıştır. Ölçeğin yedinci maddesine en fazla kızların \% 64.5'i, erkeklerin \% 58.7'si "katılıyorum/kesinlikle katılıyorum" şeklinde cevaplamıştır. Ölçeğin sekizinci maddesine en fazla kızların \% 80.2 'si, erkeklerin \% 72.5' ' "katılıyorum/kesinlikle katıllyorum” şeklinde cevaplamıştır. Ölçeğin dokuzuncu maddesine en fazla kızların \% 78.7'si, erkeklerin \% 70.2'si "katılıyorum/kesinlikle katılıyorum" şeklinde cevaplamıştır. Ölçeğin onuncu maddesine en fazla kızların \% 78.5'i, erkeklerin \% 66.5'i "katılıyorum/kesinlikle katılıyorum" şeklinde cevaplamıştır. Ölçeğin on birinci maddesine en fazla kızların \% 72.1'i, erkeklerin \% 67.1'i "katıllyorum/kesinlikle katıllyorum" şeklinde cevaplamıştır. Ölçeğin on ikinci maddesine en fazla k1zların \% 85.1'i, erkeklerin \% 74.6's1 "katılıyorum/kesinlikle katılıyorum" şeklinde cevaplamıştır. Ölçeğin on üçüncü maddesine en fazla kızların \% 75.7'si, erkeklerin \% 66.2'si “katılıyorum/kesinlikle katılıyorum" şeklinde cevaplamıştır. Ölçeğin on dördüncü maddesine en fazla kızların \% 41.1'i, erkeklerin \% 42.7'si “kat1lıyorum/kesinlikle kat1lyorum” şeklinde cevaplamıştır. Ölçeğin on beşinci maddesine en fazla erkeklerin \% 35'i "hiç katılmıyorum/katılmıyorum” şeklinde; kızların en fazla \% 43.4'ü "kararsızım” şeklinde cevaplamıştır. Ölçeğin on altıncı maddesine en fazla kızların \% 38.3'ü, erkeklerin \% 36.8'i "katılıyorum/kesinlikle katılıyorum" şeklinde cevaplamıştır. Ölçeğin on yedinci maddesine en fazla kızların \% 73.3'ü, erkeklerin \% 72.9'u "katılıyorum/kesinlikle katılıyorum" şeklinde cevaplamıştır.

\section{B. Ortaöğretim Öğrencilerinin Geribildirim Deneyimlerinin Sınıf Düzeyi Değişkeni Açısından Frekans ve Yüzde Bulguları}

Ortaöğretim öğrencilerinin sınıf düzeyi değişkeni açısından geribildirim deneyimleri incelenmiş ve bulgular Tablo 5'de verilmiştir.

Tablo 5: Ortaöğretim öğrencilerinin geribildirim deneyimlerinin sınıf düzeyi değişkeni açısından yüzde ve frekans sonuçları

\begin{tabular}{|c|c|c|c|c|c|c|c|c|c|c|c|c|c|c|c|c|}
\hline \multirow{3}{*}{ 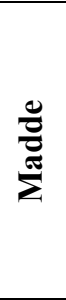 } & \multicolumn{8}{|c|}{ Hiç Katılmıyorum } & \multicolumn{8}{|c|}{ Katılmıyorum } \\
\hline & \multicolumn{2}{|c|}{ 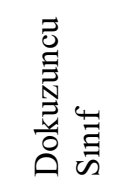 } & \multicolumn{2}{|c|}{ 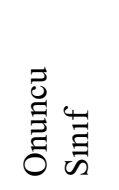 } & \multicolumn{2}{|c|}{ 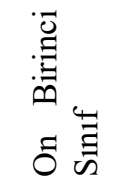 } & \multicolumn{2}{|c|}{ 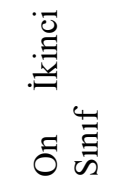 } & \multicolumn{2}{|c|}{ 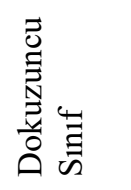 } & \multicolumn{2}{|c|}{ 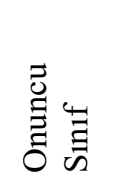 } & \multicolumn{2}{|c|}{ 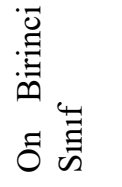 } & \multicolumn{2}{|c|}{ 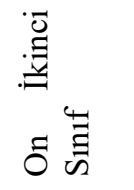 } \\
\hline & $\mathrm{f}$ & $\%$ & $\mathrm{f}$ & $\%$ & $\mathrm{f}$ & $\%$ & $\mathrm{f}$ & $\%$ & $\mathrm{f}$ & $\%$ & $\mathrm{f}$ & $\%$ & $\mathrm{f}$ & $\%$ & $\mathrm{f}$ & $\%$ \\
\hline 1 & 6 & 2.2 & 3 & 1.1 & 3 & 1.2 & 11 & 4.5 & 10 & 3.7 & 7 & 2.5 & 8 & 3.2 & 7 & 2.9 \\
\hline 2 & 5 & 1.9 & 2 & 0.7 & 1 & 4.4 & 12 & 5.0 & 21 & 7.8 & 18 & 6.4 & 22 & 8.8 & 24 & 9.9 \\
\hline 3 & 10 & 3.7 & 9 & 3.2 & 10 & 4.0 & 14 & 5.8 & 16 & 5.9 & 24 & 8.6 & 23 & 9.2 & 27 & 11.2 \\
\hline 4 & 9 & 3.3 & 6 & 2.1 & 11 & 4.4 & 14 & 5.8 & 12 & 4.5 & 24 & 8.6 & 17 & 6.8 & 23 & 9.5 \\
\hline 5 & 6 & 2.2 & 4 & 1.4 & 5 & 2.0 & 11 & 4.5 & 10 & 3.7 & 5 & 1.8 & 6 & 2.4 & 10 & 4.1 \\
\hline 6 & 9 & 3.3 & 4 & 1.4 & 4 & 1.6 & 13 & 5.4 & 9 & 3.3 & 7 & 2.5 & 6 & 2.4 & 9 & 3.7 \\
\hline 7 & 10 & 3.7 & 10 & 3.6 & 5 & 2.0 & 10 & 4.1 & 16 & 5.9 & 16 & 5.7 & 20 & 8.0 & 15 & 6.2 \\
\hline
\end{tabular}


Seçil TURAN

A T A S OBED

299 Özlem KORAY Emine KAHRAMAN

\begin{tabular}{lcccccccccccccccc}
\hline $\mathbf{8}$ & 9 & 3.3 & 4 & 1.4 & 4 & 1.6 & 12 & 5.0 & 8 & 3.0 & 9 & 3.2 & 12 & 4.8 & 19 & 7.9 \\
$\mathbf{9}$ & 7 & 2.6 & 7 & 2.5 & 4 & 1.6 & 10 & 4.1 & 19 & 7.1 & 15 & 5.4 & 15 & 6.0 & 16 & 6.6 \\
$\mathbf{1 0}$ & 10 & 3.7 & 8 & 2.9 & 10 & 4.0 & 13 & 5.4 & 16 & 5.9 & 18 & 6.4 & 15 & 6.0 & 17 & 7.0 \\
$\mathbf{1 1}$ & 9 & 3.3 & 7 & 2.5 & 4 & 1.6 & 15 & 6.2 & 13 & 4.8 & 17 & 6.1 & 22 & 8.8 & 17 & 7.0 \\
$\mathbf{1 2}$ & 2 & 0.7 & 2 & 0.7 & 7 & 2.8 & 11 & 4.5 & 12 & 4.5 & 4 & 1.4 & 11 & 4.4 & 11 & 4.5 \\
$\mathbf{1 3}$ & 10 & 3.7 & 8 & 2.9 & 4 & 5.6 & 14 & 5.8 & 17 & 6.3 & 16 & 5.7 & 15 & 6.0 & 12 & 5.0 \\
$\mathbf{1 4}$ & 22 & 8.2 & 19 & 6.8 & 21 & 8.4 & 24 & 9.9 & 43 & 16.0 & 53 & 18.9 & 46 & 18.4 & 50 & 20.7 \\
$\mathbf{1 5}$ & 36 & 13.4 & 36 & 12.9 & 24 & 9.6 & 39 & 16.1 & 40 & 14.9 & 52 & 18.6 & 61 & 24.4 & 41 & 16.9 \\
$\mathbf{1 6}$ & 26 & 9.7 & 27 & 9.6 & 27 & 10.8 & 31 & 12.8 & 49 & 18.2 & 57 & 20.4 & 42 & 16.8 & 50 & 20.7 \\
$\mathbf{1 7}$ & 11 & 4.1 & 8 & 2.9 & 11 & 4.4 & 12 & 5.0 & 14 & 5.2 & 8 & 2.9 & 15 & 6.0 & 14 & 5.8 \\
\hline
\end{tabular}

Tablo 5. devamı

\begin{tabular}{|c|c|c|c|c|c|c|c|c|c|c|c|c|c|c|c|c|}
\hline \multirow{3}{*}{ 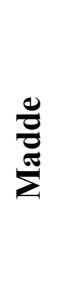 } & \multicolumn{8}{|c|}{ Kararsızım } & \multicolumn{8}{|c|}{ Katılıyorum } \\
\hline & \multicolumn{2}{|c|}{ 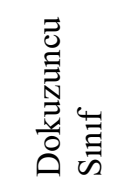 } & \multicolumn{2}{|c|}{ 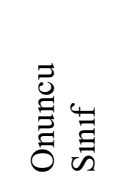 } & \multicolumn{2}{|c|}{ 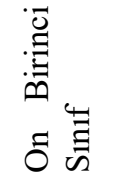 } & \multicolumn{2}{|c|}{ 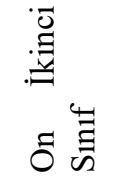 } & \multicolumn{2}{|c|}{ 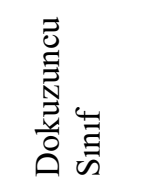 } & \multicolumn{2}{|c|}{ 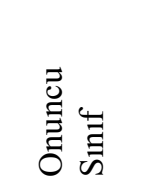 } & \multicolumn{2}{|c|}{ 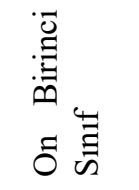 } & \multicolumn{2}{|c|}{ 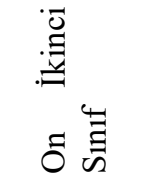 } \\
\hline & $\mathrm{f}$ & $\%$ & $\mathrm{f}$ & $\%$ & $\mathrm{f}$ & $\%$ & $\mathrm{f}$ & $\%$ & $\mathrm{f}$ & $\%$ & $\mathrm{f}$ & $\%$ & $f$ & $\%$ & $\mathrm{f}$ & $\%$ \\
\hline 1 & 29 & 10.8 & 34 & 12.1 & 42 & 16.8 & 28 & 11.6 & 135 & 50.2 & 162 & 57.9 & 120 & 48.0 & 121 & 50.0 \\
\hline 2 & 47 & 17.5 & 66 & 23.6 & 51 & 20.4 & 46 & 19.0 & 121 & 45.0 & 134 & 47.9 & 111 & 44.4 & 111 & 45.9 \\
\hline 3 & 60 & 22.3 & 69 & 24.6 & 61 & 24.4 & 60 & 24.8 & 123 & 45.7 & 135 & 48.2 & 127 & 50.8 & 100 & 41.3 \\
\hline 4 & 60 & 22.3 & 62 & 22.1 & 50 & 20.0 & 51 & 21.1 & 112 & 41.6 & 132 & 47.1 & 114 & 45.6 & 93 & 38.4 \\
\hline 5 & 33 & 12.3 & 36 & 12.9 & 49 & 19.6 & 42 & 17.4 & 104 & 38.7 & 134 & 47.9 & 116 & 46.4 & 82 & 33.9 \\
\hline 6 & 38 & 14.1 & 46 & 16.4 & 51 & 20.4 & 38 & 15.7 & 137 & 50.9 & 154 & 55.0 & 125 & 50.0 & 104 & 43.0 \\
\hline 7 & 63 & 23.4 & 99 & 35.4 & 69 & 27.6 & 70 & 28.9 & 18 & 43.9 & 121 & 43.2 & 108 & 43.2 & 89 & 36.8 \\
\hline 8 & 43 & 16.0 & 50 & 17.9 & 46 & 18.4 & 34 & 14.0 & 131 & 48.7 & 154 & 55.0 & 132 & 52.8 & 93 & 38.4 \\
\hline 9 & 40 & 14.9 & 54 & 19.4 & 38 & 15.2 & 44 & 18.2 & 119 & 44.2 & 125 & 44.8 & 125 & 50.0 & 104 & 43.0 \\
\hline 10 & 44 & 16.4 & 50 & 17.9 & 52 & 20.8 & 39 & 16.1 & 109 & 40.5 & 116 & 41.4 & 99 & 39.6 & 105 & 43.4 \\
\hline 11 & 53 & 19.7 & 60 & 21.4 & 55 & 22.0 & 47 & 19.4 & 121 & 45.0 & 137 & 48.9 & 110 & 44.0 & 90 & 37.2 \\
\hline 12 & 38 & 14.1 & 46 & 16.4 & 40 & 16.0 & 31 & 12.8 & 110 & 40.9 & 125 & 44.6 & 108 & 43.2 & 107 & 44.2 \\
\hline 13 & 45 & 16.7 & 58 & 20.7 & 49 & 19.6 & 49 & 20.2 & 123 & 45.7 & 141 & 50.4 & 114 & 45.6 & 109 & 45.0 \\
\hline 14 & 82 & 30.5 & 105 & 37.5 & 80 & 32.0 & 59 & 24.4 & 85 & 31.6 & 77 & 27.5 & 72 & 28.8 & 73 & 30.2 \\
\hline 15 & 95 & 35.3 & 120 & 42.9 & 90 & 36.0 & 80 & 33.1 & 69 & 25.7 & 56 & 20.0 & 55 & 22.0 & 53 & 21.9 \\
\hline 16 & 82 & 30.5 & 98 & 35.0 & 82 & 32.8 & 80 & 33.1 & 87 & 32.3 & 73 & 26.1 & 76 & 30.4 & 56 & 23.1 \\
\hline 17 & 37 & 13.8 & 50 & 17.9 & 39 & 15.6 & 33 & 13.7 & 107 & 39.8 & 143 & 51.1 & 118 & 47.2 & 112 & 46.5 \\
\hline
\end{tabular}


Ortaöğretim Öğrencilerinin Geribildirim Deneyimlerinin Cinsiyet, Sinıf ve Okul

Tablo 5. devam1

\begin{tabular}{|c|c|c|c|c|c|c|c|c|c|c|c|c|c|c|c|}
\hline \multirow{3}{*}{ 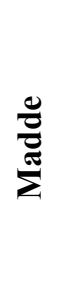 } & \multicolumn{7}{|c|}{ Kesinlikle Katılıyorum } & \multicolumn{8}{|c|}{ Toplam } \\
\hline & \multirow{2}{*}{ 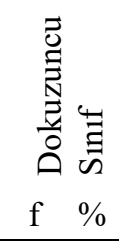 } & \multicolumn{2}{|c|}{ 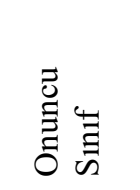 } & \multicolumn{2}{|c|}{ 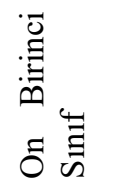 } & \multicolumn{2}{|c|}{ 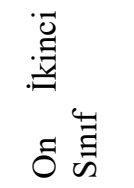 } & \multicolumn{2}{|c|}{ 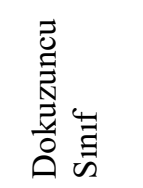 } & \multicolumn{2}{|c|}{ 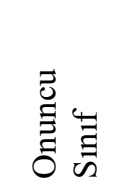 } & \multicolumn{2}{|c|}{ 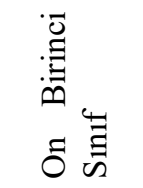 } & \multicolumn{2}{|c|}{ 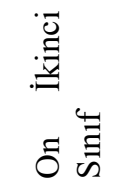 } \\
\hline & & $\mathrm{f}$ & $\%$ & $f$ & $\%$ & $\mathrm{f}$ & $\%$ & $\mathrm{f}$ & $\%$ & $\mathrm{f}$ & $\%$ & $\mathrm{f}$ & $\%$ & $\mathrm{f}$ & $\%$ \\
\hline 1 & 8933.1 & 74 & 26.4 & 77 & 30.8 & 75 & 31.0 & 269 & 100 & 280 & 100 & 250 & 100 & 242 & 100 \\
\hline 2 & 7527.9 & 60 & 21.4 & 55 & 22.0 & 49 & 20.2 & 269 & 100 & 280 & 100 & 250 & 100 & 242 & 100 \\
\hline 3 & 6022.3 & 43 & 15.4 & 29 & 11.6 & 41 & 16.9 & 269 & 100 & 280 & 100 & 250 & 100 & 242 & 100 \\
\hline 4 & 7628.3 & 56 & 20.0 & 58 & 23.2 & 61 & 25.2 & 269 & 100 & 280 & 100 & 250 & 100 & 242 & 100 \\
\hline 5 & 1643.1 & 101 & 36.1 & 74 & 29.6 & 97 & 1 & 269 & 100 & 280 & 100 & 250 & 100 & 242 & 100 \\
\hline 6 & 7628.3 & 69 & 24.6 & 64 & 25.6 & 78 & 32.2 & 269 & 100 & 280 & 100 & 250 & 100 & 242 & 100 \\
\hline 7 & 6223.0 & 34 & 12.1 & 48 & 19.2 & 58 & 24.0 & 269 & 100 & 280 & 100 & 250 & 100 & 242 & 100 \\
\hline 8 & 7829.0 & 63 & 22.5 & 56 & 22.4 & 84 & 34.7 & 269 & 100 & 280 & 100 & 250 & 100 & 242 & 100 \\
\hline 9 & 8431.2 & 78 & 28.0 & 68 & 27 & 68 & 28 & 269 & 100 & 279 & 100 & 250 & 100 & 242 & 100 \\
\hline 10 & 9033.5 & 88 & 31.4 & 74 & 29.6 & 68 & 28.1 & 269 & 100 & 280 & 100 & 250 & 100 & 242 & 100 \\
\hline 11 & 7327.1 & 59 & 21.1 & 59 & 23.6 & 73 & 30.2 & 269 & 100 & 280 & 100 & 250 & 100 & 242 & 100 \\
\hline 12 & 10739.8 & 103 & 36.8 & 84 & 33.6 & 82 & 33.9 & 269 & 100 & 280 & 100 & 250 & 100 & 242 & 100 \\
\hline 13 & 7427.5 & 57 & 20.4 & 58 & 23.2 & 58 & 24.0 & 269 & 100 & 280 & 100 & 250 & 100 & 242 & 100 \\
\hline 14 & 3713.8 & 26 & 9.3 & 31 & 12.4 & 36 & 14.9 & 269 & 100 & 280 & 100 & 250 & 100 & 242 & 100 \\
\hline 15 & 2910.8 & 16 & 5.7 & 20 & 8.0 & 29 & 12.0 & 269 & 100 & 280 & 100 & 250 & 100 & 242 & 100 \\
\hline 16 & $25 \quad 9.3$ & 25 & 8.9 & 23 & 9.2 & 25 & 10.3 & 269 & 100 & 280 & 100 & 250 & 100 & 242 & 100 \\
\hline 17 & 10037.2 & 71 & 25.4 & 67 & 26.8 & 70 & 29.0 & 269 & 100 & 280 & 100 & 250 & 100 & 241 & 100 \\
\hline
\end{tabular}

Tablo 5'e göre GDÖ'de birinci maddesine öğrencilerin en fazla dokuzuncu sinıf düzeyindeki \% 83.3'ü, onuncu sınıf düzeyindeki \% 84.3'ü, on birinci sınıf düzeyindeki \% 78.8'i ve on ikinci sınıf düzeyindeki \% 81'i "katılıyorum/kesinlikle katılıorum" şeklinde cevaplamıştır. Ölçeğin ikinci maddesine öğrencilerin en fazla dokuzuncu sınıf düzeyindeki \% 72.9'u, onuncu sınıf düzeyindeki \% 69.3'ü, on birinci sınıf düzeyindeki $\%$ 66.4'ü ve on ikinci sınıf düzeyindeki \% 66.1'i "katılıyorum/kesinlikle katılıyorum" şeklinde cevaplamıştır. Ölçeğin üçüncü maddesine öğrencilerin en fazla dokuzuncu sınıf düzeyindeki \% 68'i, onuncu sınıf düzeyindeki \% 63.3'ü, on birinci sınıf düzeyindeki \% 62.4 'ü ve on ikinci sınıf düzeyindeki \% 58.3'ü "katılıyorum/kesinlikle katılıyorum" şeklinde cevaplamıştır. Ölçeğin dördüncü maddesine öğrencilerin en fazla dokuzuncu sınıf düzeyindeki \% 69.9'u, onuncu sinıf düzeyindeki \% 67.1'i, on birinci sinıf düzeyindeki \% 68.8'i ve on ikinci sınıf düzeyindeki \% 63.6'sı "katılıyorum/kesinlikle katılıyorum" şeklinde cevaplamıştır. Ölçeğin beşinci maddesine öğrencilerin en fazla dokuzuncu sınıf düzeyindeki \% 81.8'i, onuncu sınıf düzeyindeki \% 83.9'u, on birinci sınıf düzeyindeki \% 76'sı ve on ikinci sınıf düzeyindeki \%74'ü “katılıyorum/kesinlikle katılıyorum" şeklinde cevaplamıştır. Ölçeğin altıncı maddesine öğrencilerin en fazla 
dokuzuncu sınıf düzeyindeki \% 79.2'si, onuncu sınıf düzeyindeki \% 79.6's1, on birinci sınıf düzeyindeki \% 75.6's1 ve on ikinci sınıf düzeyindeki $\%$ 75.2'si "katılıyorum/kesinlikle katılıyorum" şeklinde cevaplamıştır. Ölçeğin yedinci maddesine öğrencilerin en fazla dokuzuncu sınıf düzeyindeki \% 66.9'u, onuncu sınıf düzeyindeki $\% 55.4$ 'ü, on birinci sınıf düzeyindeki \% 62.4'ü ve on ikinci sınıf düzeyindeki \% 60.7'si "katılıyorum/kesinlikle katılıyorum" şeklinde cevaplamıştır. Ölçeğin sekizinci maddesine öğrencilerin en fazla dokuzuncu sınıf düzeyindeki \% 77.7'si, onuncu sınıf düzeyindeki $\% 77.5^{\prime} \mathrm{i}$, on birinci sınıf düzeyindeki $\% 75.2$ 'si ve on ikinci sınıf düzeyindeki \% 73.1'i "katılıyorum/kesinlikle katıllıorum" şeklinde cevaplamıştır. Ölçeğin dokuzuncu maddesine öğrencilerin en fazla dokuzuncu sınıf düzeyindeki \% 75.5 'i, onuncu sinıf düzeyindeki $\% 72.8$ 'i, on birinci sunıf düzeyindeki $\% 77.2$ 'si ve on ikinci sınıf düzeyindeki \% 71.1'i "katıliyorum/kesinlikle katıllyorum" şeklinde cevaplamıştır. Ölçeğin onuncu maddesine öğrencilerin en fazla dokuzuncu sınıf düzeyindeki $\% 74$ 'ü, onuncu sınıf düzeyindeki $\% 72.9$ 'u, on birinci sınıf düzeyindeki $\%$ 69.2'si ve on ikinci sınıf düzeyindeki \% 71.5'i "katıllyorum/kesinlikle katıllyorum" şeklinde cevaplamıştır. Ölçeğin on birinci maddesine öğrencilerin en fazla dokuzuncu sınıf düzeyindeki $\% 72.1$ ' $\mathrm{i}$, onuncu sınıf düzeyindeki $\% 70$ 'i, on birinci sınıf düzeyindeki \% 67.6'sı ve on ikinci sinıf düzeyindeki \% 67.4'ü "katılıyorum/kesinlikle katılıyorum" şeklinde cevaplamıştır. Ölçeğin on ikinci maddesine öğrencilerin en fazla dokuzuncu sınıf düzeyindeki $\% 14.1$ ' $\mathrm{i}$, onuncu sınıf düzeyindeki $\% 16.4$ 'ü, on birinci sınıf düzeyindeki $\% 16$ 'sı ve on ikinci sınıf düzeyindeki \% 12.8'i "kararsızım" şeklinde cevaplamıştır. Ölçeğin on üçüncü maddesine öğrencilerin en fazla dokuzuncu sınıf düzeyindeki \% 73.2'si, onuncu sinıf düzeyindeki $\%$ 70.7'si, on birinci sınıf düzeyindeki $\% 68.8$ 'i ve on ikinci sınıf düzeyindeki \% 69'u "katıllyorum/kesinlikle katıllyorum" şeklinde cevaplamıştır. Ölçeğin on dördüncü maddesine öğrencilerin en fazla dokuzuncu sınıf düzeyindeki $\% 45.4$ 'ü, onuncu sınıf düzeyindeki $\% 36.8$ 'i, on birinci sınıf düzeyindeki $\% 41.2$ 'si ve on ikinci sınıf düzeyindeki $\% 45$ 'i "katılıyorum/kesinlikle katıliyorum" şeklinde cevaplamıştır. Ölçeğin on beşinci maddesine öğrencilerin en fazla dokuzuncu sınıf düzeyindeki \% 35.3'ü, onuncu sınıf düzeyindeki \% 42.9'u, on birinci sınıf düzeyindeki \% 36'sı ve on ikinci sınıf düzeyindeki \% 33.1'i “kararsızım” ş̧eklinde cevaplamıştır. Ölçeğin on altıncı maddesine öğrencilerin en fazla dokuzuncu sınıf düzeyindeki $\% 41.6$ 'sı, onuncu sınıf düzeyindeki $\% 35^{\prime} \mathrm{i}$, on birinci sınıf düzeyindeki \% 39.6 's1 ve on ikinci sinıf düzeyindeki \% 33.5'i "katıllyorum/kesinlikle katllıyorum" şeklinde cevaplamıştır. Ölçeğin on yedinci maddesine öğrencilerin en fazla dokuzuncu sınıf düzeyindeki \% 77'si, onuncu sınıf düzeyindeki $\% 76.4$ 'ü, on birinci sınıf düzeyindeki $\% 74$ 'ü ve on ikinci sinıf düzeyindeki $\% 75.5$ 'i "kattlıyorum/kesinlikle katılıyorum" şeklinde cevaplamıştır.

\section{Ortaöğretim Öğrencilerinin Geribildirim Deneyimlerinin Okul Düzeyi Değişkeni Açısından Frekans ve Yüzde Bulguları}

Ortaöğretim öğrencilerinin okul düzeyi değişkeni açısından geribildirim deneyimleri incelenmiş ve bulgular Tablo 6'da verilmiştir. 
Ortaöğretim Öğrencilerinin Geribildirim Deneyimlerinin Cinsiyet, Sinıf ve Okul

Tablo 6: Ortaöğretim öğrencilerinin geribildirim deneyimlerinin okul düzeyi değişkeni açısından yüzde ve frekans sonuçları

\begin{tabular}{|c|c|c|c|c|c|c|c|c|c|c|c|c|}
\hline \multirow[b]{3}{*}{ Madde } & \multicolumn{6}{|c|}{ Hiç Katılmıyorum } & \multicolumn{6}{|c|}{ Katılmıyorum } \\
\hline & \multicolumn{2}{|c|}{$\begin{array}{l}\text { Birinci } \\
\text { Düzey }\end{array}$} & \multicolumn{2}{|c|}{$\begin{array}{l}\text { İkinci } \\
\text { Düzey }\end{array}$} & \multicolumn{2}{|c|}{$\begin{array}{l}\text { Üçüncü } \\
\text { Düzey }\end{array}$} & \multicolumn{2}{|c|}{$\begin{array}{l}\text { Birinci } \\
\text { Düzey }\end{array}$} & \multicolumn{2}{|c|}{$\begin{array}{l}\text { İkinci } \\
\text { Düzey }\end{array}$} & \multicolumn{2}{|c|}{$\begin{array}{l}\text { Üçüncü } \\
\text { Düzey }\end{array}$} \\
\hline & $\mathrm{f}$ & $\%$ & $\mathrm{f}$ & $\%$ & $\mathrm{f}$ & $\%$ & $\mathrm{f}$ & $\%$ & $\mathrm{f}$ & $\%$ & $\mathrm{f}$ & $\%$ \\
\hline 1 & 4 & 0.9 & 11 & 3.0 & 8 & 3.5 & 13 & 2.9 & 12 & 3.3 & 7 & 3.1 \\
\hline 2 & 9 & 2.0 & 16 & 4.4 & 5 & 2.2 & 23 & 5.1 & 31 & 8.5 & 31 & 13.7 \\
\hline 3 & 13 & 2.9 & 19 & 5.2 & 11 & 4.9 & 31 & 6.9 & 37 & 10.2 & 22 & 9.7 \\
\hline 4 & 10 & 2.2 & 18 & 5.0 & 12 & 5.3 & 23 & 5.1 & 31 & 8.5 & 22 & 9.7 \\
\hline 5 & 5 & 1.1 & 11 & 3.0 & 10 & 4.4 & 6 & 1.3 & 11 & 3. & 14 & 6.2 \\
\hline 6 & 7 & 1.5 & 15 & 4.1 & 8 & 3.5 & 8 & 1.8 & 15 & 4.1 & 8 & 3.5 \\
\hline 7 & 13 & 2.9 & 14 & 3.9 & 8 & 3.5 & 29 & 6.4 & 24 & 6.6 & 14 & 6.2 \\
\hline 8 & 4 & 0.9 & 12 & 3.3 & 13 & 5.8 & 14 & 3.1 & 20 & 5.5 & 14 & 6.2 \\
\hline 9 & 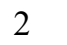 & 0.4 & 14 & 3.9 & 12 & 5.3 & 15 & 3.3 & 26 & 7.2 & 24 & 10.6 \\
\hline 10 & 8 & 1.8 & 16 & 4.4 & 17 & 7.5 & 17 & 3.8 & 21 & 5.8 & 28 & 12.4 \\
\hline 11 & 5 & 1.1 & 15 & 4.1 & 15 & 6.6 & 17 & 3.8 & 32 & 8.8 & 20 & 8.8 \\
\hline 12 & 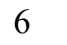 & 1.3 & 7 & 1.9 & 9 & 4.0 & 4 & 0.9 & 16 & 4. & 18 & 8.0 \\
\hline 13 & 12 & 2.7 & 19 & 5.2 & 15 & 6.6 & 17 & 3.8 & 22 & 6.1 & 21 & 9.3 \\
\hline 14 & 22 & 4.9 & 40 & 11.0 & 24 & 10.6 & 83 & 18.4 & 64 & 17.6 & 45 & 19.9 \\
\hline 15 & 33 & 7.3 & 69 & 19.0 & 33 & 14.6 & 80 & 17.7 & 70 & 19.3 & 44 & 19.5 \\
\hline 16 & 34 & 7.5 & 42 & 11.6 & 35 & 15.5 & 84 & 18.6 & 70 & 19.3 & 44 & 19.5 \\
\hline 17 & 11 & 2.4 & 16 & 4.4 & 15 & 6.6 & 13 & 2.9 & 19 & 5.2 & 19 & 8.4 \\
\hline
\end{tabular}

Tablo 6. devamı

\begin{tabular}{|c|c|c|c|c|c|c|c|c|c|c|c|c|}
\hline \multirow[b]{3}{*}{ Madde } & \multicolumn{6}{|c|}{ Kararsızım } & \multicolumn{6}{|c|}{ Katılıyorum } \\
\hline & \multicolumn{2}{|c|}{$\begin{array}{l}\text { Birinci } \\
\text { Düzey }\end{array}$} & \multicolumn{2}{|c|}{$\begin{array}{l}\text { İkinci } \\
\text { Düzey }\end{array}$} & \multicolumn{2}{|c|}{$\begin{array}{l}\text { Üçüncü } \\
\text { Düzey }\end{array}$} & \multicolumn{2}{|c|}{$\begin{array}{l}\text { Birinci } \\
\text { Düzey }\end{array}$} & \multicolumn{2}{|c|}{$\begin{array}{l}\text { İkinci } \\
\text { Düzey }\end{array}$} & \multicolumn{2}{|c|}{$\begin{array}{l}\text { Üçüncü } \\
\text { Düzey }\end{array}$} \\
\hline & $\mathrm{f}$ & $\%$ & $\mathrm{f}$ & $\%$ & $\mathrm{f}$ & $\%$ & $\mathrm{f}$ & $\%$ & $\mathrm{f}$ & $\%$ & $\mathrm{f}$ & $\%$ \\
\hline 1 & 50 & 11.1 & 45 & 12.4 & 38 & 16.8 & 236 & 52.2 & 192 & 52.9 & 110 & 48.7 \\
\hline 2 & 86 & 19.0 & 75 & 20.7 & 49 & 21.7 & 229 & 50.7 & 153 & 42.1 & 95 & 42.0 \\
\hline 3 & 102 & 22.6 & 89 & 24.5 & 59 & 26.1 & 234 & 51.8 & 152 & 41.9 & 99 & 43.8 \\
\hline 4 & 88 & 19.5 & 82 & 22.6 & 53 & 23.5 & 217 & 48.0 & 148 & 40.8 & 86 & 38.1 \\
\hline 5 & 59 & 13.1 & 50 & 13.8 & 51 & 22.6 & 207 & 45.8 & 142 & 39.1 & 87 & 38.5 \\
\hline 6 & 57 & 12.6 & 66 & 18.2 & 50 & 22.1 & 254 & 56.2 & 161 & 44.4 & 105 & 46.5 \\
\hline 7 & 144 & 31.9 & 88 & 24.2 & 69 & 30.5 & 186 & 41.2 & 160 & 44.1 & 90 & 39.8 \\
\hline 8 & 73 & 16.2 & 58 & 16.0 & 42 & 18.6 & 243 & 53.8 & 171 & 47.1 & 96 & 42.5 \\
\hline 9 & 71 & 15.7 & 69 & 19.0 & 37 & 16.4 & 232 & 51.3 & 154 & 42.4 & 87 & 38.5 \\
\hline 10 & 68 & 15.0 & 63 & 17.4 & 54 & 23.9 & 217 & 48.0 & 138 & 38.0 & 74 & 32.7 \\
\hline 11 & 83 & 18.4 & 82 & 22.6 & 50 & 22.1 & 229 & 50.7 & 139 & 38.3 & 90 & 39.8 \\
\hline 12 & 57 & 12.6 & 55 & 15.2 & 43 & 19.0 & 222 & 49.1 & 145 & 39.9 & 83 & 36.7 \\
\hline 13 & 73 & 16.2 & 76 & 20.9 & 52 & 23.0 & 241 & 53.3 & 158 & 43.5 & 88 & 38.9 \\
\hline
\end{tabular}


Seçil TURAN

303 Özlem KORAY

A T A S O B ED

Emine KAHRAMAN

202125 (Özel Sayı): 290-312

\begin{tabular}{lllllllllllll}
\hline $\mathbf{1 4}$ & 160 & 35.4 & 109 & 30.0 & 57 & 25.2 & 135 & 29.9 & 99 & 27.3 & 73 & 32.3 \\
$\mathbf{1 5}$ & 197 & 43.6 & 130 & 35.8 & 58 & 25.7 & 111 & 24.6 & 64 & 17.6 & 58 & 25.7 \\
$\mathbf{1 6}$ & 159 & 35.2 & 121 & 33.3 & 62 & 27.4 & 140 & 31.0 & 94 & 25.9 & 58 & 25.7 \\
$\mathbf{1 7}$ & 74 & 16.4 & 51 & 14.1 & 34 & 15.0 & 236 & 52.2 & 162 & 44.8 & 82 & 36.3 \\
\hline
\end{tabular}

Tablo 6. devamı

\begin{tabular}{|c|c|c|c|c|c|c|c|c|c|c|c|c|}
\hline \multirow[b]{4}{*}{ Madde } & \multicolumn{6}{|c|}{ Kesinlikle Katılıyorum } & \multicolumn{6}{|c|}{ Toplam } \\
\hline & \multirow{2}{*}{\multicolumn{2}{|c|}{$\begin{array}{l}\text { Birinci } \\
\text { Düzey }\end{array}$}} & \multirow{2}{*}{\multicolumn{2}{|c|}{$\begin{array}{l}\text { İkinci } \\
\text { Düzey }\end{array}$}} & \multirow{2}{*}{\multicolumn{2}{|c|}{$\begin{array}{l}\text { Üçüncü } \\
\text { Düzey }\end{array}$}} & \multirow{2}{*}{\multicolumn{2}{|c|}{$\begin{array}{l}\text { Birinci } \\
\text { Düzey }\end{array}$}} & \multirow{2}{*}{\multicolumn{2}{|c|}{$\begin{array}{l}\text { İkinci } \\
\text { Düzey }\end{array}$}} & \multirow{2}{*}{\multicolumn{2}{|c|}{$\begin{array}{l}\text { Üçüncü } \\
\text { Düzey }\end{array}$}} \\
\hline & & & & & & & & & & & & \\
\hline & $\mathrm{f}$ & $\%$ & $\mathrm{f}$ & $\%$ & $\mathrm{f}$ & $\%$ & $\mathrm{f}$ & $\%$ & f & $\%$ & $\mathrm{f}$ & $\%$ \\
\hline 1 & 149 & 33.0 & 103 & 28.4 & 63 & 27.9 & 452 & 100 & 363 & 100 & 226 & 100 \\
\hline 2 & 105 & 23.2 & 88 & 24.2 & 46 & 20.4 & 452 & 100 & 363 & 100 & 226 & 100 \\
\hline 3 & 72 & 15.9 & 66 & 18.2 & 35 & 15.5 & 452 & 100 & 363 & 100 & 226 & 100 \\
\hline 4 & 114 & 25.2 & 84 & 23.1 & 53 & 23.5 & 452 & 100 & 363 & 100 & 226 & 100 \\
\hline 5 & 175 & 38.7 & 149 & 41.0 & 64 & 28.3 & 452 & 100 & 363 & 100 & 226 & 100 \\
\hline 6 & 126 & 27.9 & 106 & 29.2 & 55 & 24.3 & 452 & 100 & 363 & 100 & 226 & 100 \\
\hline 7 & 80 & 17.7 & 77 & 21.2 & 45 & 19.9 & 452 & 100 & 363 & 100 & 226 & 100 \\
\hline 8 & 118 & 26.1 & 102 & 28.1 & 61 & 27.0 & 452 & 100 & 363 & 100 & 226 & 100 \\
\hline 9 & 132 & 29.2 & 100 & 27.5 & 66 & 29.2 & 452 & 100 & 363 & 100 & 226 & 100 \\
\hline 10 & 142 & 31.4 & 125 & 34.4 & 53 & 23.5 & 452 & 100 & 363 & 100 & 226 & 100 \\
\hline 11 & 118 & 26.1 & 95 & 26.2 & 51 & 22.6 & 452 & 100 & 363 & 100 & 226 & 100 \\
\hline 12 & 163 & 36.1 & 140 & 38.6 & 73 & 32.3 & 452 & 100 & 363 & 100 & 226 & 100 \\
\hline 13 & 109 & 24.1 & 88 & 24.2 & 50 & 22.1 & 452 & 100 & 363 & 100 & 226 & 100 \\
\hline 14 & 52 & 11.5 & 51 & 14.0 & 27 & 11.9 & 452 & 100 & 363 & 100 & 226 & 100 \\
\hline 15 & 31 & 6.9 & 30 & 8.3 & 33 & 14.6 & 452 & 100 & 363 & 100 & 226 & 100 \\
\hline 16 & 35 & 7.7 & 36 & 9.9 & 27 & 11.9 & 452 & 100 & 363 & 100 & 226 & 100 \\
\hline 17 & 118 & 26.1 & 114 & 31.5 & 76 & 33.6 & 452 & 100 & 362 & 100 & 226 & 100 \\
\hline
\end{tabular}

Tablo 6'dan elde edilen verilere göre GDÖ'de birinci maddesine, okul düzeyine göre en fazla öğrenciler birinci düzey \% 85.2'si, ikinci düzey \% 81.3'ü, üçüncü düzey \% 76.5'i "katılıyorum/kesinlikle katılıyorum" şeklinde cevaplamıştır. Ölçeğin ikinci maddesine, okul düzeyine göre en fazla öğrenciler birinci düzey \% 66.4'u, üçüncü düzey \% 62.4'ü "katılıyorum/kesinlikle katılıyorum" şeklinde cevaplamıştır. Ölçeğin üçüncü maddesine, okul düzeyine göre en fazla öğrenciler birinci düzey \% 67.7'si, ikinci düzey \% 60.1'i ve üçüncü düzey \% 59.3'ü "katılıyorum/kesinlikle katılıyorum” şeklinde cevaplamıştır. Ölçeğin dördüncü maddesine, okul düzeyine göre en fazla öğrenciler birinci düzey \% 73.2'si, ikinci düzey $\% \quad 63.9^{\prime}$ u ve üçüncü düzey $\% \quad 61.5$ 'i "katılıyorum/kesinlikle katılıyorum" şeklinde cevaplamıştır. Ölçeğin beşinci maddesine, okul düzeyine göre en fazla öğrenciler birinci düzey \% 84.5'i, ikinci düzey \% 80.2'si ve üçüncü düzey \% 66.8'i "katılıyorum/kesinlikle katılıyorum" şeklinde cevaplamıştır. Ölçeğin altıncı maddesine, okul düzeyine göre en fazla öğrenciler birinci düzey \% 84.1'i, 
ikinci düzey \% 73.6'sı ve üçüncü düzey \% 70.8'i "katılıyorum/kesinlikle katılıyorum" şeklinde cevaplamıştır. Ölçeğin yedinci maddesine, okul düzeyine göre en fazla öğrenciler birinci düzey \% 58.8'i, ikinci düzey \% 65.3'ü ve üçüncü düzey \% 59.7'si "katılıyorum/kesinlikle katılıyorum" şeklinde cevaplamıştır. Ölçeğin sekizinci maddesine, okul düzeyine göre en fazla öğrenciler birinci düzey \% 79.9'u, ikinci düzey \% 75.2'si ve üçüncü düzey \% 69.5'i “katılıyorum/kesinlikle katılıyorum” şeklinde cevaplamıştır. Ölçeğin dokuzuncu maddesine, okul düzeyine göre en fazla öğrenciler birinci düzey $\% 80.5^{\prime} \mathrm{i}$, ikinci düzey $\% 70$ 'i ve üçüncü düzey \% 67.7'si "katılıyorum/kesinlikle katılıyorum" şeklinde cevaplamıştır. Ölçeğin onuncu maddesine, okul düzeyine göre en fazla ögrenciler birinci düzey \% 79.4'ü, ikinci düzey \% 72.5'i ve üçüncü düzey \% 56.2'si “katılıyorum/kesinlikle katılıyorum” şeklinde cevaplamıştır. Ölçeğin on birinci maddesine, okul düzeyine göre en fazla öğrenciler birinci düzey \% 76.8'i, ikinci düzey \% 64.5'i ve üçüncü düzey \% 62.4'ü "katıllyorum/kesinlikle katılıyorum" şeklinde cevaplamıştır. Ölçeğin on ikinci maddesine, okul düzeyine göre en fazla öğrenciler birinci düzey \% 85.2'si, ikinci düzey $\% 78.5^{\prime}$ 'i ve üçüncü düzey \% 69'u "katılıyorum/kesinlikle katılıyorum" şeklinde cevaplamıştır. Ölçeğin on üçüncü maddesine, okul düzeyine göre en fazla öğrenciler birinci düzey \% 77.4'ü, ikinci düzey \% 67.8'i ve üçüncü düzey \% 61.1'i "kat1lyorum/kesinlikle katıllyorum” şeklinde cevaplamıştır. Ölçeğin on dördüncü maddesine, okul düzeyine göre en fazla öğrenciler birinci düzey \% 41.4'ü, ikinci düzey \% 41.3’ü ve üçüncü düzey \% 44.2'si "katılıyorum/kesinlikle katılıyorum" şeklinde cevaplamıştır. Ölçeğin on beşinci maddesine, okul düzeyine göre en fazla öğrenciler birinci düzey \% 43.6's1 ve ikinci düzey \% 35.8'i “kararsızım” şeklinde; üçüncü düzey \% 40.3'u “katılıyorum/kesinlikle katılıyorum" şeklinde cevaplamıştır. Ölçeğin on altıncı maddesine, okul düzeyine göre en fazla öğrenciler birinci düzey \% 38.7'si, ikinci düzey \% 35.8'i ve üçüncü düzey \% 37.6's1 "katılıyorum/kesinlikle katılıyorum" şeklinde cevaplamıştır. Ölçeğin on yedinci maddesine, okul düzeyine göre en fazla öğrenciler birinci düzey \% 78.3'ü, ikinci düzey \% 76.2'si ve üçüncü düzey \% 69.9'u “katılıyorum/kesinlikle katılıyorum” şeklinde cevaplamıştır.

\section{Ortaöğretim Öğrencilerinin Cinsiyet Değişkeni Açısından Geribildirim Deneyimlerinin Farklılaşıp Farklılaşmadığına İlişkin Bulgular}

Ortaöğretim öğrencilerinin cinsiyet değişkeni açısından geribildirim deneyimlerine ilişkin bulgular Tablo 7'de verilmiştir.

Tablo 7: Ortaöğretim öğrencilerinin geribildirim deneyimlerinin cinsiyet değişkenine göre Mann Whitney U analizi sonuçları

\begin{tabular}{llllll}
\hline Grup & N & $\begin{array}{l}\text { Sira } \\
\text { Ortalaması }\end{array}$ & Sira Toplamı & U & p \\
\hline K1Z & 470 & 569.62 & 267720.5 & 111334.5 & 0.00 \\
Erkek & 571 & 480.98 & 274640.5 & & \\
\hline
\end{tabular}

Tablo 7'de göre ortaöğretim öğrencilerinin cinsiyet değişenine göre geribildirim deneyimlerinde anlamlı bir farklılık bulunmaktadır $(\mathrm{U}=111334.5, \mathrm{p}<.01)$. Geribildirim 
deneyimi puanlarının sıra ortalamaları dikkate alındığında kız öğrencilerin puanlarının (569.62), erkek öğrencilerin puanlarından (480.98) daha yüksek olduğu bulunmuştur.

\section{E. Ortaöğretim Öğrencilerinin Sınıf Düzeyi Değişkeni Açısından Geribildirim Deneyimlerinin Farklılaşıp Farklılaşmadığına İlişkin Bulgular}

Ortaöğretim öğrencilerinin sınıf düzeyi değişkeni açısından geribildirim deneyimlerine ilişskin bulgular Tablo 8'de verilmiştir.

Tablo 8: Ortaöğretim öğrencilerinin geribildirim deneyimlerinin sınıf düzeyi değişkenine göre Kruskal-Wallis H testi analizi sonuçları

\begin{tabular}{llllll}
\hline Grup & n & Sira Ortalamasi & sd & $\mathbf{X}^{\mathbf{2}}$ & $\mathbf{p}$ \\
\hline Dokuzuncu sinıf & 269 & 558.71 & 3 & 6.32 & 0.09 \\
Onuncu sinıf & 280 & 508.73 & & & \\
On birinci sinıf & 250 & 496.96 & & & \\
On ikinci sinıf & 242 & 518.11 & & & \\
\hline
\end{tabular}

Tablo 8'e göre ortaöğretim öğrencilerinin sınıf düzeyi değişkeni dikkate alındığında geribildirim deneyimlerinde anlamlı bir farklılık göstermemektedir $\left(X^{2}(\mathrm{sd}=3, \mathrm{n}=1041)=\right.$ $6.32, \mathrm{p}>.05$ ). Elde edilen bu bulgudan ortaöğretim öğrencilerinin sinıf düzeyleri değiştikçe geribildirim deneyimlerinin değişmediği belirlenmiştir. Tablo 8'de verilen sıra ortalamalarına göre dokuzuncu sınıfların (558.71) geribildirim deneyimlerinin en yüksek olduğu ve bunu sirasıyla on ikinci (518.11), onuncu (508.73) ve on birinci (496.96) sınıfların izlediği belirlenmiştir.

F. Ortaöğretim Öğrencilerinin Okul Düzeyi Değişkeni Açısından Geribildirim Deneyimlerinin Farklılaşıp Farklılaşmadığına İlişkin Bulgular

Ortaöğretim öğrencilerinin okul düzeyi değişkeni açısından geribildirim deneyimlerine ilişkin bulgular Tablo 9'da verilmiştir.

Tablo 9: Ortaöğretim öğrencilerinin geribildirim deneyimlerinin okul düzeyi değişkenine göre Kruskal-Wallis H testi analizi sonuçları

\begin{tabular}{llllll}
\hline Grup & n & Sıra Ortalaması sd & $\mathbf{X}^{\mathbf{2}}$ & $\mathbf{p}$ \\
\hline Birinci Düzey & 452 & 528.06 & 2 & 4.59 & 0.10 \\
İkinci Düzey & 363 & 495.69 & & & \\
Üçüncü Düzey & 226 & 547.54 & & & \\
\hline
\end{tabular}

Tablo 9'a göre ortaöğretim öğrencilerinin okul düzeyi değişkenine göre geribildirim deneyimleri anlamlı bir farkl1lık göstermemektedir $\left(X^{2}(\mathrm{sd}=3, \mathrm{n}=1041)=4.59, \mathrm{p}>.05\right)$. Elde edilen bu bulgudan ortaöğretim öğrencilerinin okul düzeyi değiştikçe geribildirim deneyimlerinin değişmediği belirlenmiştir. Tablo 9'da verilen sıra ortalamalarına göre üçüncü düzey (547.54) okulun geribildirim deneyimlerinin en yüksek olduğu ve bunu sırasıyla birinci düzey (528.06) ve ikinci düzey (547.54) okulların izlediği belirlenmiştir. 
Ortaöğretim Öğrencilerinin Geribildirim Deneyimlerinin Cinsiyet, Sinıf ve Okul Düzeyi Değişkenleri Açısından İncelenmesi

\section{Tartışma, Sonuç ve Öneriler}

Ortaöğretim öğrencilerinin geribildirim deneyimlerinin cinsiyet, sınıf ve okul düzeyi değişkenleri açısından incelendiği bu araştırmada ulaşılan sonuçlar şu şekildedir. Ortaöğretim öğrencilerinin cinsiyet değişkenine göre geribildirim deneyimleri incelendiğinde, kız öğrencilerin lehine anlamlı bir farklılık bulunmuştur. Kız öğrenciler erkek öğrencilere göre verilen geribildirimlerin, değerlendirme sürecinin önemli bir bölümünü olușturduğunun farkındadırlar. Kız öğrencilerin geribildirimleri ödevlerinin düzeltilmesinde, ödevlerinin gelişmesinde, bir sonraki ödeve yardımcı olmasında ve öğrenme sürecinde kullanılan materyallerin belirlenmesinde erkek öğrencilere göre daha olumlu bir tutum sergiledikleri belirlenmiştir. Hem kız hem de erkek öğrenciler öğrenme sürecinde geribildirimleri büyük oranda kullandıklarını belirtmişlerdir. Öğrenciler geribildirimlerin konunun eksik veya yanlış kısımlarının farkına varılmasını sağlayarak, ileriki çalı̧̧alara ışık tuttuğunu vurgulamışlardır. Ayrıca tüm öğrenciler geribildirimlerin konunun anlamlı ve kalıcı olarak öğrenmesine katkı sağlayarak, kaliteli öğrenmeyi gerçekleştirdiğini düşünmektedirler.

Alan yazında yer alan çalışmalar incelendiğinde cinsiyet değişkenine göre öğrencilerin geribildirim deneyimlerinin farklılık gösterdiği çalı̧̧malar bulunmaktadır (Hassan \& Arslan, 2018; Zarei, 2011). Hassan ve Arslan (2018) öğrenciler ve İngilizce öğretmenleriyle yaptıkları çalışmada, erkek ve kız öğrencilerin düzeltici geri bildirim tercihlerinin farklı olduğunu belirtmişlerdir. Yine, Zarei (2011) tarafından yapılan çalışmada da erkek ve kız öğrencilerin geribildirim deneyimleri arasında istatistiksel olarak anlamlı bir fark olduğu görülmüştür. Ancak bu bulguların aksine, Park (2010) çalışmasında öğrenme anında veya sonrasında verilen geribildirimlerin cinsiyet açısından bir farklılık yaratmadığını belirtmiştir. Benzer şekilde, Khorshidi ve Rassaei (2013) İranlı öğrencilerle yaptığı çalışmada erkek ve kız öğrencilerin geribildirim deneyimlerinde anlamlı bir farklılık bulamamıştır. Literatürde yapılan çalışmalar, kız ve erkek öğrencilerin öğrenme sürecinde geribildirimleri büyük oranda kullandıkları görülmüştür (Geçkin, 2020; Katayama, 2007; Park, 2010). Bu çalışmalardan birini Geçkin (2020) 100 öğrenciyle (50 kız, 50 erkek) gerçekleştirmiş olup, çalışmada cinsiyet farklılıklarının öğrencilerin sözlü düzeltici geri bildirim inanışları üzerindeki etkisini incelemiştir. Çalışma sonunda hem erkek hem de kız katılımcılar özellikle ciddi ve bireysel hatalarına verilen geribildirimleri, öğrenme süreçleri için gerekli bir bileşen olarak görmüşler ve öğretmenin verdiği geri bildirimi daha olumlu değerlendirmişlerdir.

Ortaöğretim öğrencilerinin geribildirim deneyimleri sınıf düzeyi değişkenine göre incelendiğinde sınıf düzeyleri arasında anlamlı farklılık olmadığı bulunmuştur. Öğrenciler bütün sınıf düzeylerinde geribildirimleri deneyimlediklerini, fakat farkındalığın dokuzuncu sınıf ögrencilerinde en yüksek olduğunu, bunu sırasıyla on ikici, onuncu ve on birinci sınıf düzeylerinin izlediği belirlenmiştir. Bütün sınıf seviyelerindeki öğrenciler geribildirimin, değerlendirme sürecinin önemli bir parçası olduğunun farkındadırlar. Ancak ödevleri için aldıkları geribildirimlerin kendilerine yardımcı olduğuna olan inançları, ödevlerini yaparlarken geribildirimlerden yararlanmaları konularında ve geribildirimlerden yararlanma seviyeleri sınıf düzeyleri yükseldikçe azalmaktadır. Dokuzuncu ve onuncu sınıf seviyesindeki öğrenciler verilen 
geribildirimlerin, eksik veya yanlı̧ bilgilerin fark edilmesini ve öğrenmede kalitenin artmasını sağladığı için yol gösterici olduğunu düşünmektedirler. On birinci ve on ikinci sınıf öğrencileri de verilen geribildirimlerin öğrenmenin kalitesini arttırdı̆̆ını düşünmelerine rağmen, geribildirimlerin öğrenmede etkililiğine olan inançları diğer sınıf seviyelerine göre daha düşüktür. Bütün sınıf düzeylerinde öğrenciler sınav sonrasında verilen geribildirimlerin, öğrenmelerini olumlu etkilediğini düşünmektedirler. Öğrenciler başarı düzeyleri ile ilgili verilen geribildirimlerden yararlandıklarını ve bu bilgilerin kendilerine dönüş süresinin uzun olduğunu belirtmişlerdir.

Çalışma sonucunun aksine, literatürde farklı sınıf seviyelerinde kullanılan geribildirim seviyelerinin birbirinden farklı olduğunu ortaya koyan çalışmalar bulunmaktadır (Burnett, 2001; Burnett \& Mandel, 2010; Koç, 2020; Ok \& Ustacı, 2013). Ok ve Ustacı (2013)'nın üniversite öğrencileriyle (birinci, ikinci, üçüncü ve dördüncü sınıf) yaptığı çalışmada, dördüncü sınıftaki öğrencilerin verilen geribildirimlere daha olumlu ve hassas yaklaşım gösterdiğini ve birinci sınıf öğrencilerinin diğer seviyedeki öğrencilere kıyasla daha fazla geri bildirime ihtiyaç duyduklarını tespit etmiş̧lerdir. Koç (2020) tarafından yapılan bir diğer araştırmada da, ortaokul matematik öğretmenlerinin ders ortamlarında kullandıkları geri bildirim türleri ve bu geri bildirimlerin sınıf düzeyine göre nasıl farklılaştığını incelemiştir. Araştırmanın sonucunda ortaokul matematik öğretmenlerinin 5. ve 6.sınıflardaki değerlendirici geri bildirim kullanma tercihlerini, 7.ve 8.sınıflarda betimleyici geri bildirimlere yönelttiklerini tespit etmiştir. Yine, Burnett ve Mandel (2010) öğretmenlerin ders ortamında kullandıkları geri bildirimleri ve öğrencilerin geri bildirim algılarını inceledikleri çalışmalarında ilkokul düzeyindeki öğrencilerin değerlendirici geri bildirimleri, ortaokul düzeyindeki öğrencilerin ise gösterdikleri çabaya yönelik geri bildirimleri tercih ettikleri görülmüştür. Bununla birlikte Burnett (2001) yaptığı çalışmada öğrencilerin sınıf düzeyleri arttıkça çaba temelli geri bildirim isteyenlerin sayısının arttı̆̆ını belirtmiştir.

Ortaöğretim öğrencilerinin geribildirim deneyimleri okul düzeyine göre anlamlı bir farkl11ık göstermemektedir. Çalışmada öğrencilerin bütün okul düzeylerinde geribildirimleri deneyimledikleri, fakat farkındalığın başarı puanı düşük olan üçüncü okul düzeyinde en yüksek olduğu, bunu sırasıyla başarı puanı yüksek olan birinci ve başarı puanı orta olan ikinci düzey okulların izlediği bulunmuştur. Ortaöğretim öğrencilerinin geribildirim deneyimleri okul düzeyi değişkenine göre incelendiğinde; bütün okul düzeylerinde geribildirimin öğrenme sürecinin etkili bir bölümü olarak kabul edilmesine rağmen, başarı puanı düşük üçüncü okul düzeyinin başarı puanı yüksek olan birinci okul düzeyinden nispeten farklı olduğu tespit edilmiştir. Geribildirimleri, başarı puanı yüksek olan birinci okul düzeyindeki öğrenciler eksik ve hatalarını düzeltmek, ödevlerin düzenlenmesinde kullanılan kaynaklara yönlendirmesi nedeniyle daha çok kullanmaktadırlar. Her üç okul düzeyindeki öğrenciler, verilen geribildirimlerin birçoğunun kendi performanslarını geliştirecek nitelikte olmadığını belirtmişlerdir. Benzer şekilde Koç (2020) çalışmasında öğretmenlerin en sık kullandıkları geribildirimin öğrencinin başarısını takdir etme olduğunu ancak, öğrenciye ayrıcalıklı davranma ve potansiyelini geliştirme geribildiriminin öğretmenler tarafından hiçbir sınıf 
Ortaögrretim Öğrencilerinin Geribildirim Deneyimlerinin Cinsiyet, Sinıf ve Okul Düzeyi Değişkenleri Açısından İncelenmesi

düzeyinde kullanılmadığını tespit etmiştir. Fidan (2015) tarafından yapılan başka bir çalışmada, İngilizce öğrenen iki farklı seviyede (141 C1 seviyesi öğrenci ve 24 B2 seviyesi öğrenci) eğitim alan öğrencilerin tamamının eğitim sürecinde hemen geribildirim verilmesi gerektiğini belirterek, hatalarının düzeltilmesini tercih ettiklerini ifade etmişlerdir.

Öğrenme ve öğretme sürecinde konunun anlaşılıp anlaşılmadığını tespit etmek için yapılan değerlendirmeler ve bilgilendirmeler öğretimin ana etkinliğidir. Bu süreçte kullanılan geribildirimler öğrenmeyi daha kalıcı hale getirmektedir (Hattie \& Timperley, 2007). Alan yazında yapılmış çalışmalar araştırma sonucuyla örtüşmektedir. Geribildirim mesajını inceleyen bazı araştırmalar öğrencilere sağlanan geribildirim yorumlarının doğasını incelemişlerdir (Brookhart \& Moss, 2009; Chase \& Humanas, 2009; Mutch, 2003). Örneğin betimsel bir çalışmada Mutch (2003), öğretmenlerin verdiği geribildirim mesajını incelemiş ve bu yorumların sınıflandırılabilmesinin çeşitli yöntemlerini belirlemiştir. Chase ve Humanas (2009), yaptıkları çalışmalarında öğrencilere sadece cevabın doğru ya da yanlış olduğunun söylendiği temel geribildirim ile cevabın niçin yanlış olduğu bilgisinin de verildiği detaylı geribildirimi karşılaştırmışlardır. Çalışma sonunda detaylı geribildirim alan öğrencilerin temel geribildirim alan öğrencilerden akademik yönde daha fazla gelişme kaydettikleri gözlenmiştir (Black \& William, 1998). Brookhart ve Moss (2009)'a göre etkili olarak yapılan geribildirimler öğrencilerin bilişsel işlemlerini geliştirir, onların özerkliğini artırarak esnekliğini ve sürekliliğini sağlamaktadır. Ayrıca öğrencilerin öğrenmelerinde geleceğe yönelik olarak özel stratejiler geliştirmelerine yardımcı olmaktadır. Poulos ve Mohony (2008) bir grup öğrenci üzerinde yaptıkları çalışmada geribildirimin zamanında verilmesi, geribildirimin faydalı olması, öğrenmeye katkısı olması bakımından önemlidir. Ayrıca notlandırma kriterleri üzerinde; nota ek olarak, yorum almanın da önemli olduğunu vurgulamıştır. Dolayısıyla yapılan geribildirimlerin özel, doğru, vaktinde ve amaçlı olarak yapılması gerekmektedir (Lee, 2017). Öğretmenler verdikleri geribildirimlerin amacını, gerçekleşme sürecini ve sonuçlarını doğru planlayarak, öğrencilerin öğrenme kalitesini arttırabilirler (Burnett \& Mandel, 2010; Irons, 2008; Noor, Aman, Mustaffa \& Seong, 2010). Çünkü geribildirim öncelikle öğrencilerin performansı ile ilgili öğrencilere sağlanan bilginin içeriğine odaklıdır.

$\mathrm{Bu}$ çalışmada öğrencilerin var olan geribildirim deneyimleri ve bu deneyimlerinin cinsiyet, okul ve sınıf düzeyi değişkenleri açısından nasıl farklılaştığının araştırılması için tek bir ölçek kullanılmış ve 1041 öğrenci çalışmaya dâhil edilmiştir. Bu durum araştırmanın sınırlılığg olarak düşünüldüğünde; daha farklı ölçekler ve veri toplama teknikleri kullanılabilecek ve daha fazla ortaöğretim öğrencisine ulaşılabilecek şekilde yeni çalışmalar dizayn edilebilir.

Araştırmadan elde edilen sonuçlara göre sunulan öneriler şunlardır:

$\mathrm{Bu}$ çalışmada öğrenciler, geribildirimlerin öğrenme süreçlerini etkileyerek performanslarının gelişimine katkı sağladığını düşünseler de yapılan geribildirimlerin, geri dönüşünün geç olduğunu belirtmişlerdir. Bu nedenle öğretim sürecinde kullanılan geribildirimlerin zamanlamasının doğru yapılması ve geribildirim dönüşünün erken olması gerekmektedir. Ayrıca öğretim ortamlarında kullanılan geribildirimlerin önemine 
dikkat çekmek için; geribildirim türleri, veriliş şekli ve miktarı gibi konularda öğretmenlerin bilgi düzeyini artıracak nitelikte hizmet içi eğitimler verilmesi önerilebilir. Öğrencilere verilen geribildirimler öğrencilerin ihtiyaçları doğrultusunda, sınıf seviyesi dikkate alınarak açıklanarak verilmesi gerekmektedir. Öğrencilerin yaşı, gelişim seviyesi, bilgi düzeyi ve özelliklerine göre geribildirimin türü ve şekli değişebilmektedir. Yeni yapılacak çalışmalarda öğrencilerin ailelerin sosyo-ekonomik düzeyi, ailelerin eğitim düzeyi ve öğrencilerin başarı düzeyi gibi farklı değişkenler dikkate alınarak yapılabilir. Bu çalışmada öğrencilerin geribildirim deneyimleri incelenmiştir. Gelecekte yapılacak çalışmalarda öğretmenin geribildirimi kullanma sıklığı ve şekli araştırılabilir. Öğrencilerin geribildirim deneyimleri incelenerek, akademik başarıya etkisi incelenebilir. Ayrıca öğrenci, aile ve öğretmenlerle geribildirime yönelik görüş, öneri ve sorunlar incelenebilir.

\section{Kaynaklar}

Askew, S. ve Lodge, C. (2000). "Gifts, Ping-Pong And Loops-Linking Feedback And Learning." Susan Askew (Ed.), Feedback for Learning (s.1-17) içinde. Routledge.

Atılgan, H. (2017). Eğitimde Ölçme ve Değerlendirme. Anı Yayınları.

Bahar, M., Nartgün, Z., Durmuş, S. ve Bıçak, B. (2012). Geleneksel-tamamlayıcı Ölçme ve Değerlendirme Teknikleri (5. Baskı). Pegem Akademi Yayıncılık.

Black, P. ve Wiliam, D. (1998). “Assessment and Classroom Learning”. Assessment in Education: Principles, Policy \& Practice, 5(1), 7-74.

Bose, J. ve Rengel, Z. (2009). “A Model Formative Assessment Strategy to Promote Student-Centered Self-Regulated Learning in Higher Education". US-China Education Review, 6(12), 29-35.

Brookhart, S. M. ve Moss, C. M. (2009). Advancing Formative Assessment in Every Classroom: A Guide for İnstructional Leaders. ASCD.

Burnett, P. C. (2001). “Elementary Students' Preferences For Teacher Praise. Journal of Classroom Interaction". 36(1), 16-23.

Burnett, P. C. ve Mandel, V. (2010). "Praise and Feedback in the Primary Classroom: Teachers' and Students' Perspectives". Australian Journal of Educational \& Developmental Psychology, 10, 145-154.

Butler, D. ve Winne, P. (1995). "Feedback and Self-Regulated Learning: a Theoretical Synthesis". Review of Educational Research, 65(3), 245-281.

Büyüköztürk, Ş., Kılıç Çakmak, E., Akgün, Ö. E., Karadeniz, Ş. ve Demirel, F. (2021). Eğitimde Bilimsel Araştırma Yöntemleri (30. Baskı). Pegem A Yayınları.

Cemiloğlu, M. (2001). “Anadilimiz Türkçe”. Türk Yurdu Türkçeye Saygı Dergisi, 2 (Özel Sayı), 162-163. 
Ortaöğretim Öğrencilerinin Geribildirim Deneyimlerinin Cinsiyet, Sinıf ve Okul

Chase, J. A. ve Houmanfar, R. (2009). "The Differential Effects of Elaborate Feedback and Basic Feedback on Student Performance in a Modified, Personalized System of Instruction Course". Journal of Behavioral Education, 18(3), 245-265. DOI 10.1007/s10864-009-9089-2

Doğan, C. D. (2016). "Biçimlendirici Değerlendirmenin Üniversite Öğrencilerinin Değerlendirme Tercihleri Üzerindeki Etkisi: Bir Ölçekleme Çalışması". Abant İzzet Baysal Üniversitesi Eğitim Fakültesi Dergisi, 16(2), 413-431.

Fautley, M. ve Savage, J. (2008). Assessment for Learning and Teaching in Secondary Schools. British: Learning Matters Ltd.

Fidan, D. (2015). "Learners' Preferences of Oral Corrective Feedback: An Example of Turkish as a Foreign Language Learners". Educational Research and Reviews, 10(9), 1311-1317.

Geçkin, V. (2020). "Do Gender Differences Affect Foreign Language Anxiety and Preferences for Oral Corrective Feedback?". Journal of Theoretical Educational Science, 13(3), 591-608.

Gibbs, G. ve Simpson, C. (2003). "Measuring the Response of Students to Assessment: the Assessment Experience Questionnaire". 11th Improving Student Learning Symposium, 26-30 Ağustos 2003, Padova.

Glover, C. ve Brown, E. (2006). "Written Feedback for Students: too much, too Detailed or too Incomprehensible to be Effective?". Bioscience Education, 7(1), 1-16.

Güven, İ. (2004). "Etkili Bir Öğretim İçin Öğretmenden Beklenenler”. Milli Ĕ̆gitim Dergisi, 164, 127-141.

Hassan, A. W. ve Arslan, F. Y. (2018). “A Comparative Study on Iraqi EFL Teachers' and Learners' Preferences of Corrective Feedback in Oral Communication". Bartın University Journal of Faculty of Education, 7(3), 765-785.

Hattie, J. ve Timperley, H. (2007). "The Power of Feedback". Review of Educational research, 77(1), 81-112. doi: 10.3102/003465430298487

Higgins, R., Hartley, P. ve Skelton, A. (2002). "The Conscientious Consumer: Reconsidering the Role of Weaver, M.R., 2006. Do Students Value Feedback? Students Perceptions of Tutors' Written Responses". Assessment \& Evaluation in Higher Education, 31(3), 379-394. https://doi.org/10.1080/02602930500353061

Hounsell, D. (2007). “Towards More Sustainable Feedback to Students”. D. Boud ve N. Falchikov (Ed.), Rethinking Assessment in Higher Education (s. 101-113) içinde. Routledge.

Jonsson, A. (2012). "Facilitating Productive Use of Feedback in Higher Education". Active Learning in Higher Education, 14(3), 63-76. doi: 10.1177/1469787412467125 
İlgen, D. R., Fisher, C. D. ve Taylor, M. S. (1979). "Consequences of Individual Feedback on Behavior in Organizations". Journal of Applied Psychology, 64(4), 349371.

Irons, A. (2008). Enhancing Learning Through Formative Assessment and Feedback. Routledge.

Kahraman, E. ve Koray, O. (2020). "The Use of Standardized Feedback for Teaching Material Preparation: The Opinions of Preservice Science Teachers". Eurasian Journal of Educational Research, 90, 83-102.

Karasar, N. (2020). Bilimsel Araştırma Yöntemi: Kavramlar İlkeler Teknikler (36. bask1). Nobel Yayınc1lık.

Katamaya, A. (2007). "Japanese EFL Students' Preferences toward Correction of Classroom Oral Errors”. Asian EFL Journal, 9(4), 289-305.

Khorshidi, E. ve Rassaei, E. (2013). "The Effects of Learners' Gender on their Preferences for Corrective Feedback". Jornal of Studies in Learning and Teaching English, 1(4), 71-83.

Koç, E. (2020). Ortaokul Matematik Öğretmenlerinin Ders Süreçlerinde Kullandıkları Geri Bildirimlerin Sınıf Düzeyine Göre İncelenmesi. Yüksek Lisans Tezi, Sakarya Üniversitesi, Sakarya.

Koray, O. (2016). “Pre-Service Science Teachers' Opinions about Using the Feedback Process in the Preparation of Teaching Materials". Asia-Pacific Forum on Science Learning and Teaching, 17(1), 1-20.

Korkmaz, H. (2004). Fen ve Teknoloji Eğitiminde Alternatif Değerlendirme Yaklaşımları. Yeryüzü Yayınevi.

Lee, I. (2008). "Understanding Teachers' Written Feedback Practices in Hong Kong Secondary Classrooms". Journal of Second Language Writing, 17(7), 69-85. https://doi.org/10.1016/j.jslw.2007.10.001

Lee, I. (2017). Classroom Writing Assessment and Feedback in L2 School Contexts. Springer.

Lipnevich, A. A. ve Smith, J. K. (2008). "I Really Need Feedback to Learn: Students' Perspectives on the Effectiveness of the Differential Feedback Messages. Educational Assessment". Evaluation and Accountability, 21(4), 347-367. doi: 10.1007/s11092-009-9082-2

Mandel, V. (2010). "Praise and Feedback in the Primary Classroom: Teachers' and Students' Perspectives". Australian Journal of Educational \& Developmental Psychology, 10, 145-154.

Mutch, A. (2003). "Exploring the Practice of Feedback to Student". Active Learning in Higher Education, 4(1), 24-38. 
Ortaöğretim Öğrencilerinin Geribildirim Deneyimlerinin Cinsiyet, Sinıf ve Okul

Nicol, D. J. ve Macfarlane-Dick, D. (2006). "Formative Assessment and Self-Regulated Learning: A Model and Seven Principles of Good Feedback Practice". Studies in Higher Education, 31(2), 199-218. doi: 10.1080/03075070600572090

Noor, N. M., Aman, I., Mustaffa, R. ve Seong, T. K. (2010). “Teacher’s Verbal Feedback on Students' Response: a Malaysian ESL Classroom Discourse Analysis”. ProcediaSocial and Behavioral Sciences, 7, 398-405. doi:10.1016/j.sbspro.2010.10.054

Ok, S. ve Ustac1, H. (2013). "Preferences of ELT Students on the Strategies Instructors Use in the Correction of Oral Grammar Errors". International Journal of Business and Social Science, 4(8), 244-254.

Sadler, D. R. (2010). "Beyond Feedback: Developing Student Capability in Complex Appraisal". Assessment \& Evaluation in Higher Education, 35(5), 535-550. https://doi.org/10.1080/02602930903541015

Semerci, Ç. (2008). "Eğitimde Ölçme ve Değerlendirme”. Emin Karip (Ed.), Ölçme ve Değerlendirme (s. 1-15) içinde. Pegem Akademi.

Panasuk, M. R. ve Lebaron, J. (1999). "Student Feedback: a Tool for İmproving İnstruction in Graduate Education". Education, 120(2), 356-368.

Park, G. (2010). "Preference of Corrective Feedback Approaches Perceived by Ative English Teachers and Students". The Jornal of Asia TEFL, 7(4), 29-52.

Peterson, E. R. ve Irving, S. E. (2008). "Secondary School Students' Conceptions of Assessment and Feedback". Learning and Instruction, 18(3), 238-250. https://doi.org/10.1016/j.learninstruc.2007.05.001

Poulos, A. ve Mahony, M. J. (2008). "Effectiveness of Feedback: The Students' Perspective". Assessment \& Evaluation in Higher Education, 33(2), 143-154. https://doi.org/10.1080/02602930601127869

Vollmeyer, R. ve Rheinberg, F. (2005). “A Surprising Effect of Feedback on Learning”. Learning and Instruction, 15(6), 589-602. https://doi.org/10.1016/j.learninstruc.2005.08.001

Weaver, J. (2006). "Do Students Value Feedback? Students Perceptions of Tutors' Written Responses”. Assessment \& Evaluation in Higher Education, 31(3), 379-394. https://doi.org/10.1080/02602930500353061

Zarei, N. (2011). "The Relationship Between Gender and Corrective Feedback". Online Jornal of ICT for Lanaguage Learning, 5(11), 59-79. 